\title{
The differential expression of aqueous soluble proteins in breast normal and cancerous tissues in relation to ethnicity of the patients; Chinese, Malay and Indian
}

\author{
Seng Liang ${ }^{\mathrm{a}}$, Manjit Singh ${ }^{\mathrm{b}}$ and Lay-Harn Gam ${ }^{\mathrm{a}, *}$ \\ ${ }^{a}$ School of Pharmaceutical Sciences, University Sains Malaysia, Penang, Malaysia \\ ${ }^{\mathrm{b}}$ Department of Surgery, Penang General Hospital, Penang, Malaysia
}

\begin{abstract}
Female breast cancer is one of the leading causes of female mortality worldwide. In Malaysia, breast cancer is the most commonly diagnosed cancer in women. Of the women in Malaysia, the Chinese have the highest number of breast cancer cases, followed by the Indian and the Malay. The most common type of breast cancer is infiltrating ductal carcinoma (IDC). A proteomic approach was applied in this study to identify changes in the protein profile of cancerous tissues compared with normal tissues from 18 patients; 8 Chinese, 6 Malay and 4 Indian were analysed. Twenty-four differentially expressed hydrophilic proteins were identified. We evaluated the potential of these proteins as biomarkers for infiltrating ductal carcinoma based on their ethnic-specific expressions. Three of the upregulated proteins, calreticulin, 14-3-3 protein zeta and 14-3-3 protein eta, were found to be expressed at a significantly higher level in the cancerous breast tissues when compared with the normal tissues in cases of infiltrating ductal carcinoma. The upregulation in expression was particularly dominant in the Malay cohort.
\end{abstract}

Keywords: Breast cancer, proteomics, biomarkers, ethnicity

\author{
Abbreviations \\ IDC: infiltrating ductal carcinoma \\ 2D-PAGE: two dimensional polyacryla- \\ mide gel electrophoresis \\ AEBSF: 4-(2-Aminoethyl) benzenesul- \\ fonyl fluoride \\ TCA: trichloroacetic acid \\ DTT: dithiothreitol

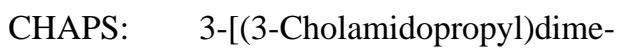 \\ thylammonio]-1-propanesulfo- \\ nate \\ RT:
}

SDS-PAGE: sodium dodecyl sulfate polyacrylamide gel electrophoresis

CBR-250: Coomassie Brilliant Blue 250

LC/MS/MS: liquid chromatography tandem mass spectrometry

ACN: acetonitrile

$\mathrm{NH}_{4} \mathrm{HCO}_{3}$ : ammonium bicarbonate

BSA: bovine serum albumin

PBS: $\quad$ phosphate buffered saline

HRP: horseradish peroxidase

4CN: 4-chloro napthtol
*Corresponding author: Dr. Lay-Harn Gam, School of Pharmaceutical Sciences, University Sains Malaysia, 11800 USM, Penang, Malaysia. Tel: +60 46533888 ext 2208; Fax: +60 46570017 ; E-mail: layharn@usm.my.

\section{Introduction}

Breast cancer is one of the leading causes of cancer deaths worldwide. It accounted for 548,000 deaths or 
$7 \%$ of all cancer deaths worldwide in 2007 and is the most common form of cancer affecting women [1,2]. It is responsible for the deaths of $\sim 30,000$ women yearly in the United States [3]. Breast cancer is the most common form of cancer in all ethnic and age groups of women in Malaysia. It is most prevalent among the Chinese, followed by the Indian and Malay, where the overall age-specific rate (ASR) was 46.2 per 100,000 women. Of these groups, Chinese females had the highest ASR of 59.7 per 100,000 women, followed by Indian females with an ASR of 55.8 per 100,000 and Malay females with an ASR of 33.9 per 100,000 [4]. One in 19 women in Malaysia runs the risk of developing breast cancer [5].

Eighty-five percent of breast cancers originate in the mammary ducts, while fifteen percent arise in the lobules, which makes ductal carcinomas the most common type of breast cancer [6]. The staging and grading of cancer are used to classify the metastasis of the disease and the biological aggressiveness of cancer cells, respectively $[7,8]$. Both staging and grading are used to determine the prognosis of a patient. Additionally, recent reports showed that the prognosis of breast cancer is affected by triple-negative breast cancer [9] as well as BRCA1 and BRCA2 mutations [10]. Caucasians have a greater incidence of breast cancer when compared to Asians, although the prognosis of both groups is similar in a stage-by-stage comparison [11]. Nevertheless, no study has documented the comparison of the prognosis between the Asian groups of Chinese, Indian and Malay women.

Although the molecular pathways involved in cancer progression have been intensively studied, their roles in the formation of cancer from normal tissue remain poorly understood [12]. Therefore, it is interesting to identify proteins that are differentially expressed in cancerous and normal breast tissues in order to understand the molecular mechanisms of breast cancer progression.

The large-scale study of the proteome, which is the entire complement of proteins expressed by an organism, is termed proteomics [13]. In general, a protein mixture can be typically separated by two-dimensional polyacrylamide gel electrophoresis (2D-PAGE) [14], after which proteins of interest can be excised from the gel and subjected to mass-spectrometry analysis for protein identification [15]. Proteomics has been used to identify protein biomarkers in breast cancer [16-20] and other types of cancers [21-24]. The identity and functional role of these biomarkers may have important prognostic value in the detection and treatment of the disease $[25,26]$.
The aim of the present study was to identify the differentially expressed aqueous soluble proteins between normal and cancerous tissues obtained from breast cancer patients. The significance of the identified protein in breast cancer will be evaluated according to their expression levels in relation to the ethnicity of the patients.

\section{Materials and methods}

\subsection{Breast cancer patients}

Patients that were afflicted with breast cancer for the first time and had not received any pre-treatment for the disease were divided by race into 3 cohorts: Chinese, Malay and Indian. The Chinese cohort contained 8 patients, the Malay cohort 6 patients and the Indian cohort 4 patients. All patients were diagnosed with infiltrating ductal carcinoma and had undergone surgical treatment at Penang Hospital, Malaysia. Human ethical clearance for conducting this study was provided by the Human ethical committee of the Ministry of Health, Malaysia and the Human ethical committee of the Universiti Sains Malaysia, Malaysia. Information about the patients involved in this study can be found in Table 1.

\subsection{Tissue samples}

Specimens of normal and cancerous breast tissue were obtained from the Penang General Hospital, Penang, Malaysia. The tissues were collected after receiving informed consent from the patients. Each pair of tissues was comprised of cancerous tissue and its neighbouring normal tissue collected from the same patient. The tissues were pathologically confirmed by the hospital's pathologist. A frozen section of tissue morphology was taken from the cancerous tissues from the anterior and deep region to ensure adequacy of the tumour and that the only part of the cancerous tissue used in this study would contain greater than $90 \%$ malignant cells. Tissues were stored at $-80^{\circ} \mathrm{C}$ until analysis.

\subsection{Protein extraction}

Frozen tissues were washed with distilled water and cut into small pieces (approximately $250 \mathrm{mg}$ ). The tissue was added with Tris buffer (TRIS) [(40 mM Tris, $1 \mathrm{mM}$ 4-(2-Aminoethyl) benzenesulfonyl fluoride (AEBSF)] at 2:1 ratio and homogenised with a plastic 
Table 1

Patient information

\begin{tabular}{|c|c|c|c|c|c|c|c|c|}
\hline Patient no. & Race & Age & Stage & TNM & Grade & Estrogen receptor & Progesterone receptor & C-ERB-B oncoprotein \\
\hline 1 & Indian & 54 & 3 & $\mathrm{~T}_{2} \mathrm{~N}_{1} \mathrm{M}_{X}$ & 1 & Positive & Positive & Negative \\
\hline 2 & Chinese & 67 & 2 & $\mathrm{~T}_{2} \mathrm{~N}_{0} \mathrm{M}_{X}$ & 3 & Negative & Negative & Negative \\
\hline 3 & Chinese & 60 & 3 & $\mathrm{~T}_{2} \mathrm{~N}_{1} \mathrm{M}_{X}$ & 2 & Positive & Positive & Positive \\
\hline 4 & Malay & 74 & 3 & $\mathrm{~T}_{2} \mathrm{~N}_{1} \mathrm{M}_{X}$ & 2 & Positive & Positive & Negative \\
\hline 5 & Malay & 67 & 3 & $\mathrm{~T}_{3} \mathrm{~N}_{1} \mathrm{M}_{X}$ & 2 & Negative & Negative & Positive \\
\hline 6 & Malay & 78 & 3 & $\mathrm{~T}_{4} \mathrm{~N}_{1} \mathrm{M}_{X}$ & 3 & Positive & Positive & Negative \\
\hline 7 & Chinese & 64 & 3 & $\mathrm{~T}_{3} \mathrm{~N}_{1} \mathrm{M}_{X}$ & 3 & Negative & Negative & Positive \\
\hline 8 & Malay & 63 & 2 & $\mathrm{~T}_{2} \mathrm{~N}_{0} \mathrm{M}_{X}$ & 3 & Positive & Negative & Positive \\
\hline 9 & Chinese & 65 & 2 & $\mathrm{~T}_{2} \mathrm{~N}_{1} \mathrm{M}_{X}$ & 3 & Negative & Negative & Negative \\
\hline 10 & Chinese & 59 & 2 & $\mathrm{~T}_{2} \mathrm{~N}_{1} \mathrm{M}_{X}$ & 3 & Negative & Negative & Negative \\
\hline 11 & Malay & 55 & 4 & $\mathrm{~T}_{4} \mathrm{~N}_{x} \mathrm{M}_{1}$ & 3 & Positive & Negative & Negative \\
\hline 12 & Chinese & 72 & 2 & $\mathrm{~T}_{2} \mathrm{~N}_{0} \mathrm{M}_{x}$ & 2 & Positive & Negative & Negative \\
\hline 13 & Chinese & 80 & 3 & $\mathrm{~T}_{3} \mathrm{~N}_{1} \mathrm{M}_{X}$ & 2 & Positive & Positive & Negative \\
\hline 14 & Chinese & 60 & 2 & $\mathrm{~T}_{2} \mathrm{~N}_{1} \mathrm{M}_{X}$ & 3 & Negative & Negative & Negative \\
\hline 15 & Malay & 62 & 2 & $\mathrm{~T}_{2} \mathrm{~N}_{1} \mathrm{M}_{X}$ & 3 & Negative & Negative & Positive \\
\hline 16 & Indian & - & 3 & $\mathrm{~T}_{4 B} \mathrm{~N}_{1} \mathrm{M}_{X}$ & 1 & Positive & Positive & Positive \\
\hline 17 & Indian & 54 & 3 & $\mathrm{~T}_{2} \mathrm{~N}_{2} \mathrm{M}_{X}$ & 2 & Negative & Negative & Negative \\
\hline 18 & Indian & 64 & 3 & $\mathrm{~T}_{3} \mathrm{~N}_{0} \mathrm{M}_{X}$ & 2 & Positive & Positive & Negative \\
\hline
\end{tabular}

homogeniser for $5 \mathrm{~min}$ on ice. The homogenate was vortexed for 30 seconds and then centrifuged (13000 $\mathrm{rpm}, 20 \mathrm{~min}, 20^{\circ} \mathrm{C}$ ). The supernatant was collected and the protein concentration was determined in duplicate by an RC-DC protein assay (Bio-Rad).

\subsection{Protein preparation}

Prior to isoelectric focusing, proteins in Tris buffer were precipitated by a trichloroacetic acid (TCA)/acetone method [27]. Tris extracts were treated with $10 \%$ TCA in ice-cold acetone containing $20 \mathrm{mM}$ dithiothreitol (DTT) and incubated for 1.5 hours at $-20^{\circ} \mathrm{C}$. After centrifugation $(13000 \mathrm{rpm}$, $\left.15 \mathrm{~min}, 4^{\circ} \mathrm{C}\right)$, the pellet was washed with ice-cold acetone with $20 \mathrm{mM}$ DTT. The solution was centrifuged $\left(13000 \mathrm{rpm}, 15 \mathrm{~min}, 4{ }^{\circ} \mathrm{C}\right)$ and the supernatant was discarded. The pellet was solubilised in thiourea lysis buffer (TLB) (8 M Urea, $2 \mathrm{M}$ Thiourea, $4 \%$ (w/v) 3-[(3-Cholamidopropyl)dimethylammonio]1-propanesulfonate (CHAPS), $0.4 \%$ (w/v) carrier ampholyte, $50 \mathrm{mM}$ DTT, $1 \mathrm{mM}$ AEBSF) and incubated for 1 hour at room temperature. Each of the tissue specimens was analysed in duplicate.

\subsection{D-gel electrophoresis}

Protein extract ( $250 \mathrm{mg}$ protein) was passively rehydrated into $11 \mathrm{~cm} \mathrm{pH} \mathrm{4-7} \mathrm{IPG} \mathrm{strips} \mathrm{(Bio-Rad)} \mathrm{for}$ 15 hours. Isoelectric focusing was performed using the Protean IEF Cell (Bio-Rad) at $20^{\circ} \mathrm{C}$ for $15 \mathrm{~min}$ at $250 \mathrm{~V}, 2.5$ hours at $8000 \mathrm{~V}$ and held at $8000 \mathrm{~V}$ for $30 \mathrm{kVh}$. The proteins were equilibrated by incu- bating the focused IPG strips in equilibration buffer I [6 M Urea, 0.375 M Tris-HCl, pH 8.8, 2\% SDS, 20\% glycerol, $1 \%(\mathrm{w} / \mathrm{v}) \mathrm{DTT}$ ] for $10 \mathrm{~min}$ at RT, followed by the addition of equilibration buffer II [6 M Urea, $0.375 \mathrm{M}$ Tris- $\mathrm{HCl}, \mathrm{pH} 8.8,2 \%$ SDS, $20 \%$ glycerol, $2.5 \%(\mathrm{w} / \mathrm{v})$ iodoacetamide] for $10 \mathrm{~min}$ at RT. The IPG strip was positioned on top of a $10 \%$ sodium dodecyl sulfate-polyacrylamide gel (SDS-PAGE) $(135 \times 160 \times$ $1 \mathrm{~mm}$ ) and electrophoresed in a PROTEAN II xi Cell (Bio-Rad) at a constant voltage of $200 \mathrm{~V}$ for 3 hours according to the method of Laemmli [28]. After electrophoresis, proteins were visualised by staining the gel with Coomassie Brilliant Blue 250 (CBR-250) solution [0.1\% (w/v) CBR-250, 40\% (v/v) methanol, $10 \%$ (v/v) acetic acid) for 4 hours. The staining background was removed by incubating the gel in a destaining solution [40\% (v/v) methanol, $2 \%(\mathrm{v} / \mathrm{v})$ acetic acid] twice for 2 hours each time.

\subsection{Gel imaging and analysis}

The 2D-PAGE images were acquired using the Versadoc system (Bio-Rad). The gel images were processed and analysed using PDQuest software (Bio$\mathrm{Rad})$. The software was used to create a matchset for a tissue specimen that was analysed in duplicate. Each specimen matchset was then used to create a master matchset to compare the individual specimen matchset of the cancerous and normal breast tissues. The master matchset was used to analyse the quantitative and qualitative differences in the protein spots between individual matchsets. Each protein spot was normalised as a percentage of the total density of all proteins spots in 
A)
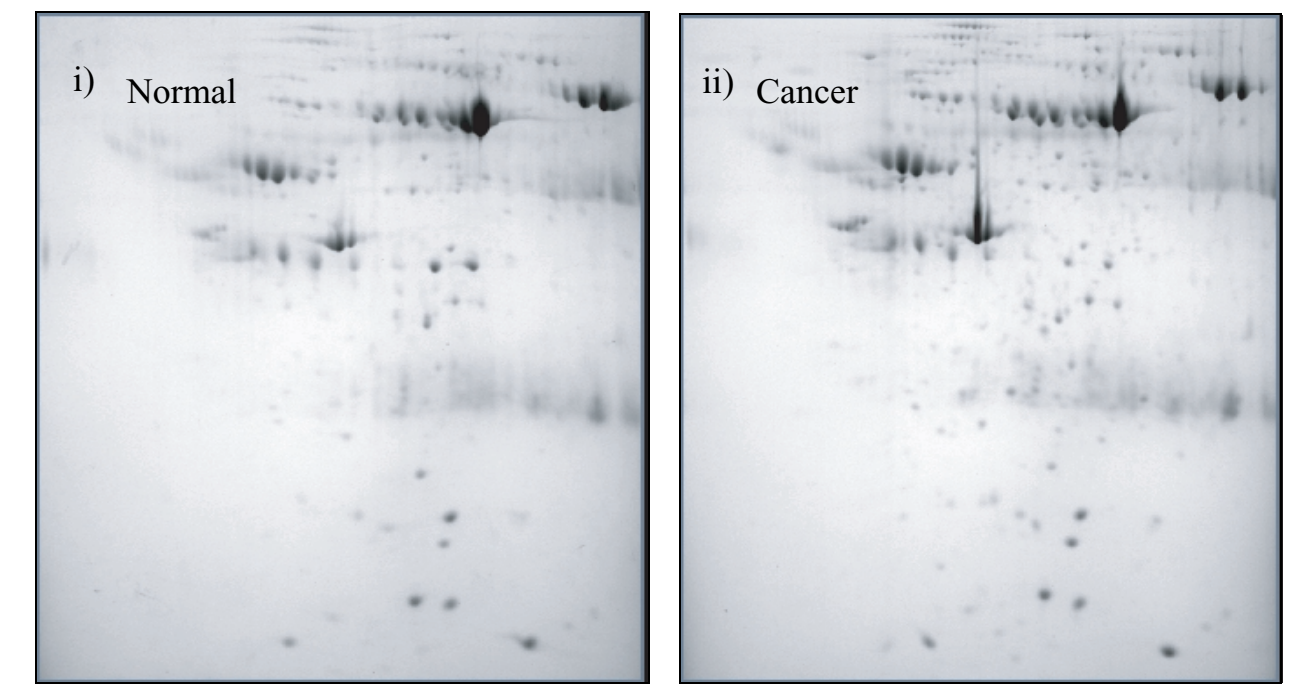

B)

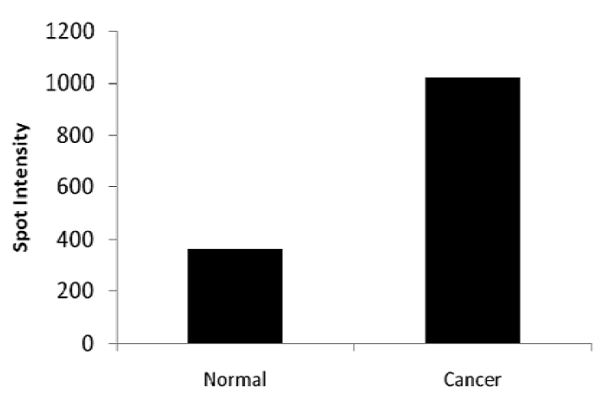

Fig. 1. a) $2 \mathrm{D}$ gel image of the Tris extract from i) Normal and ii) Cancerous breast tissues from the same patient. b) The spots intensities of i) SEC13-like 1 in normal and cancerous tissues. ii) Caltreticulin in normal and cancerous tissues. iii) Peroxiredoxin-2 in normal and cancerous tissues. iv) 14-3-3 protein zeta in normal and cancerous tissues. c) Protein spots selected for in-gel digestion from the Tris extract.

each gel in order to quantitate and to correct slight variations in protein loading. A protein was considered as upregulated if its expression level in cancerous tissues was increased 1.5-fold or more as compared to normal breast tissue; it was considered as downregulated if its expression level in cancerous tissues was decreased 1.5-fold or more as compared to normal breast tissue. A protein was uniquely expressed if it was exclusively found in either normal or cancerous breast tissue only. Additionally, the statistical significance of the protein's change in expression was determined using the Wilcoxon signed-rank test available in the PDQuest software.

\subsection{In-gel digestion and liquid chromatography tandem mass spectrometry (LC/MS/MS) analysis}

In-gel digestion was performed according to the method described by Othman et al. [29]. In summary, the protein spot of interest was excised from the gel, washed with deionised water, cut in fine pieces and dehydrated and rehydrated with acetonitrile $(\mathrm{ACN})$ and $100 \mathrm{mM}$ ammonium bicarbonate $\left(\mathrm{NH}_{4} \mathrm{HCO}_{3}\right)$, respectively, in order to remove the staining. The protein was then reduced in situ with DTT, alkylated with iodoacetamide and finally digested into peptide fragments by the trypsin enzyme. The peptide fragments were then eluted from the gel and dried under the continuous flow of nitrogen gas. Peptides were reconstituted in $30 \mu \mathrm{L}$ of $0.1 \%$ (v/v) formic acid in an 85:15 solution of deionised water and acetonitrile. Peptides were fractionated by RP-HPLC $(\mathrm{C} 18,150 \times 0.3 \mathrm{~mm}, 5 \mu \mathrm{m}, 300 \AA)$ using an Agilent 1100 Series. The mobile phases A and B were pumped at a constant flow rate of $4 \mu \mathrm{L} / \mathrm{min}$, where A was $0.1 \%$ formic acid in deionised water and $\mathrm{B}$ was $0.1 \%$ formic acid in ACN. The peptides were eluted with a linear gradient of $5 \% \mathrm{~B}$ to $95 \% \mathrm{~B}$ in $70 \mathrm{~min}$ and held constant at $95 \%$ B for 5 min. The HPLC was interfaced with an ESI-ion trap mass analyser (Agilent). Two types of scan were performed, a full scan MS and 


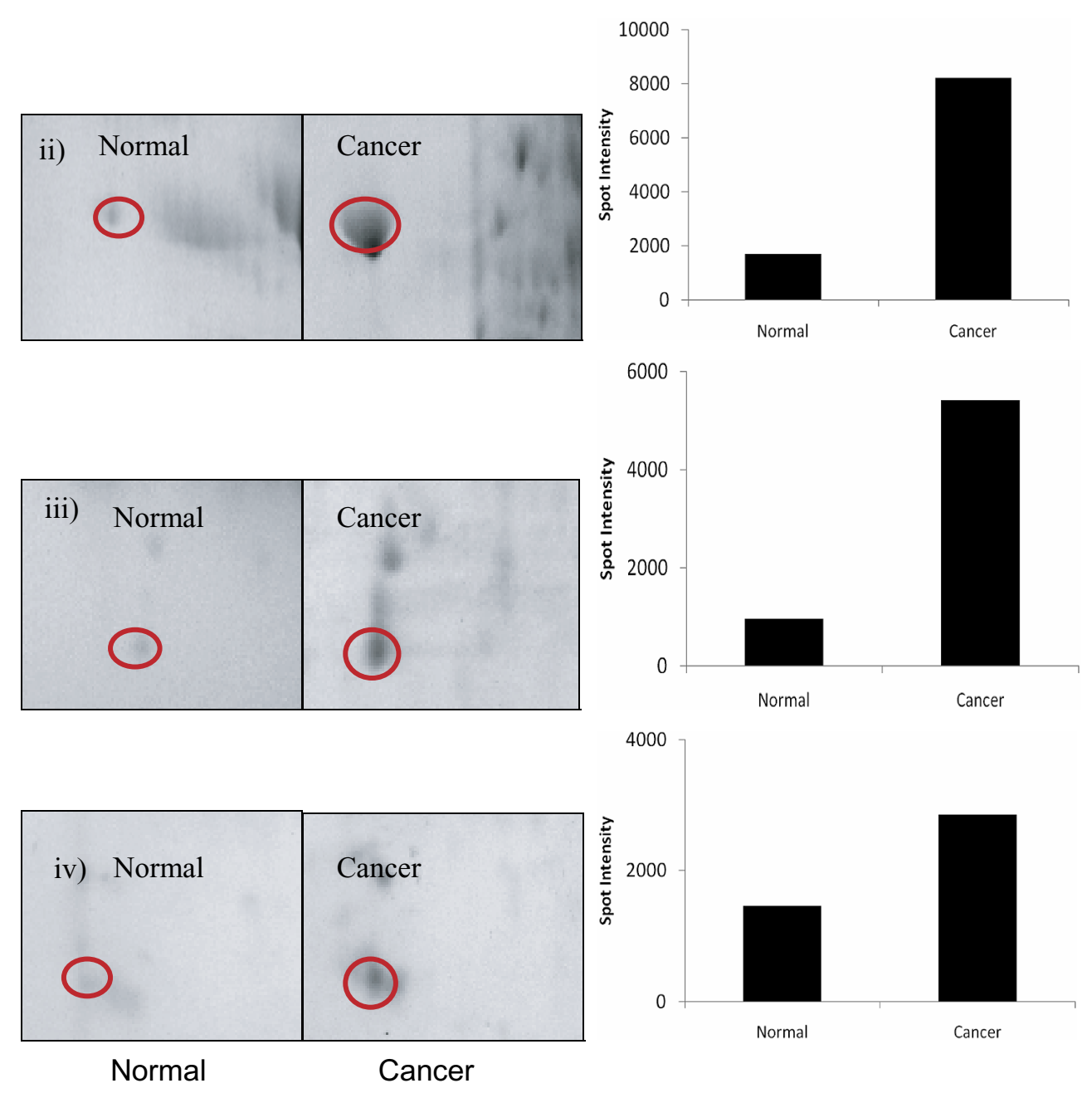

Fig. 1. continued,

a full scan MS/MS, during which the two most intense ions in a MS scan that exceeded the set threshold (5000 counts) were isolated for an MS/MS scan to produce a series of product ion spectra for the identification of the proteins. Instrumental parameters were a nebuliser pressure of $20 \mathrm{psi}$, an auxiliary dry gas flow of $6 \mathrm{~L} / \mathrm{min}$, an auxiliary dry gas temperature of $300^{\circ} \mathrm{C}$, a capillary voltage of $3.5 \mathrm{kV}$, an exit capillary voltage of $84.5 \mathrm{~V}$, a skimmer 1 voltage at $17.2 \mathrm{~V}$ and a skimmer 2 voltage of 6.0 V. The MS scan region spanned from $200-1800 \mathrm{~m} / \mathrm{z}$ with a scan time of $1 \mathrm{~s}$ and an interscan time of $0.1 \mathrm{~s}$. The parameters set for the MS/MS scan were a default collision energy (voltage) of $1.15 \mathrm{~V}$, a charge state of 2 , a minimum threshold of 5000 counts and an isolation width of $2 \mathrm{~m} / \mathrm{z}$. Proteins were identified by subjecting the MS/MS data to a MASCOT (version 2.2) search using the MASCOT database search engine (MSDB) available at http://www.matrixscience.com. The search parameters used were Homo sapiens for taxonomy, carboxymethyl for fixed modifications, a peptide tolerance of $+/-2 \mathrm{Da}$, an MS/MS tolerance of $+/-0.8 \mathrm{Da}$ and the average experimental mass value.

\subsection{Western blotting}

Western blotting was carried out using a semi-dry blotting method [30]. Protein extracts were separated by SDS-PAGE according to Laemmli [28]. The gel was equilibrated in cold transfer buffer (192 mM Glycine, $25 \mathrm{mM}$ Tris and $1.3 \mathrm{mM}$ SDS, $\mathrm{pH}$ 8.3) for 30 min. A similar quantity of each protein extract was transferred from a polyacrylamide gel to a nitrocellulose membrane (Bio-Rad) in a TE 70 Semiphor 


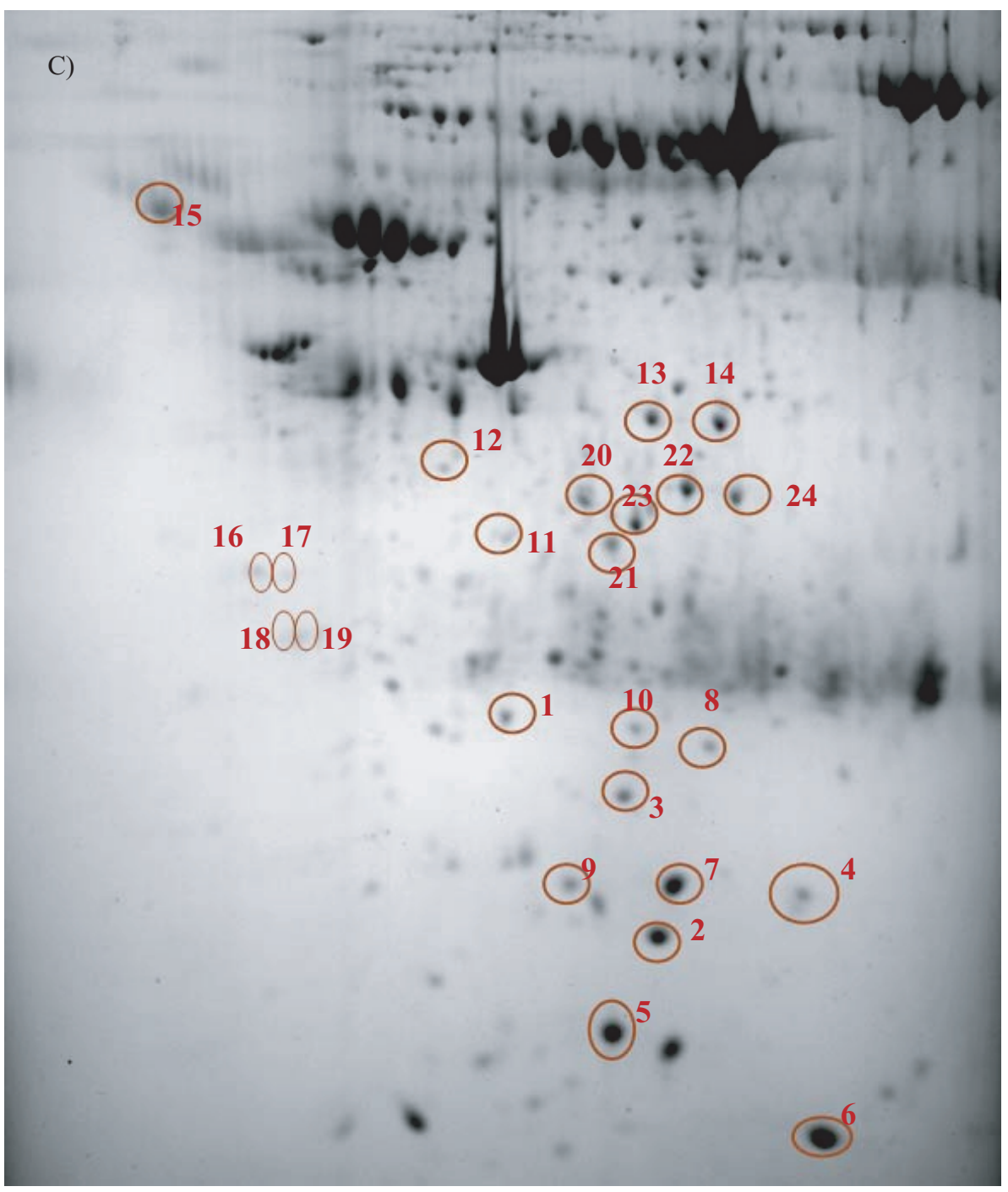

Fig. 1. continued,

semi-dry transfer unit (Hoefer Scientific, Germany) at $134 \mathrm{~mA}$ for 1.5 hours. The membrane was incubated with blocking buffer [3\% (w/v) bovine serum albumin (BSA) in phosphate buffered saline (PBS)] for 2 hours at RT. After washing, the membrane was incubated in $20 \mathrm{~mL}$ of a 1:2000 dilution of mouse anti-calreticulin antibody (Abnova, Taiwan) in antibody diluent buffer [0.1\% (w/v) BSA, $0.1 \%$ Tween 20, 0.02\% sodium azide in PBS] overnight at RT. After washing, the membrane was incubated in $50 \mathrm{~mL}$ of a 1:3000 dilution of horseradish peroxidase (HRP)-conjugated anti-mouse secondary antibody (Bio-Rad, USA) for 2 hours at RT. After washing, $20 \mathrm{~mL}$ of 4-Chloro naphthol (4CN) substrate solution (Bio-Rad, USA) was added to the mem- brane until the band appeared.

\section{Results}

Aqueous soluble proteins are comprised of cytoplasmic and nuclear proteins. Figure 1a shows an example of 2D gel images of normal and cancerous breast tissue extracts from the same patient. Both gels were run and stained under identical conditions. A relatively consistent protein profile was observed in the images amongst the same cohort. In addition to the protein spots with similar intensities, protein spots with different intensities indicated the presence of differentially expressed 

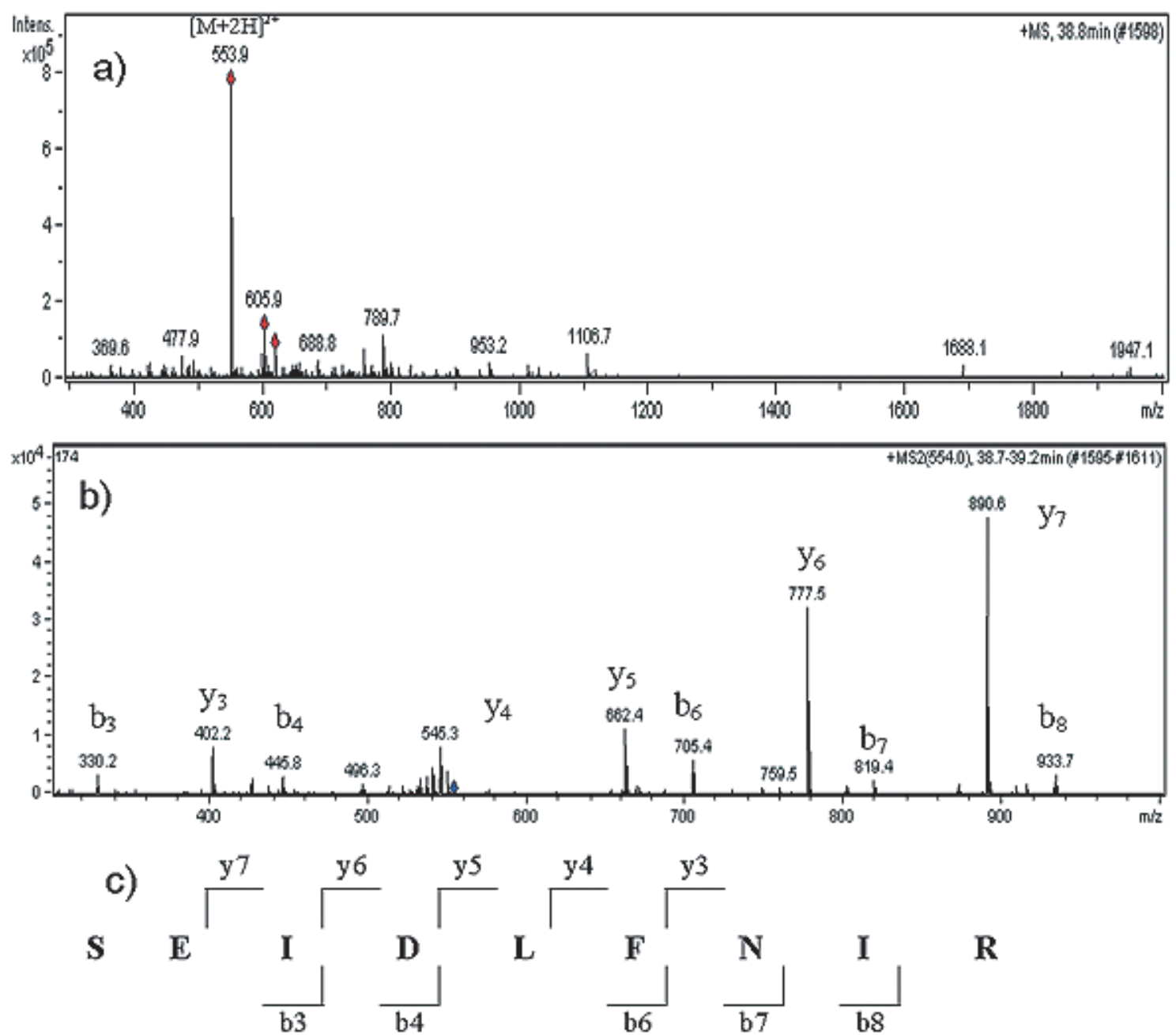

Fig. 2. Identification of proteins. a) Full scan MS spectrum of the $553.9 \mathrm{~m} / \mathrm{z}$ peptide. b) MS/MS spectra of the 553.9 product ions. c) Amino acid sequence derived from the $553.9 \mathrm{~m} / \mathrm{z}$ peptide in $\mathrm{b}$ ).

proteins between the two tissues types (Fig. 1b). The differentially expressed proteins spots with high spot intensities were targeted for LC/MS/MS analysis. The circled spots shown in Fig. 1c indicate the proteins that were further analysed.

Twenty-four protein spots with varying expression levels were targeted. The MS and MS/MS spectra of one of the target proteins are shown in Fig. 2. Upon MASCOT search, the peptide was found to belong to calreticulin. Table 2 shows the list of proteins identified in this study. GRAVY score of the proteins indicates the hydrophilicity of the proteins; the more negative a protein's score, the greater its hydrophilic properties. Table 3 shows the mean number of protein spots detected in the 2D gel images in all three cohorts. The percent coefficient variation shows a high variability in the number of protein spots detected in each patient, indicating heterogeneity of the tissues. For this reason, we only focused on the protein spots expressed with $>$ $75 \%$ consistency in patients. Four proteins were found to be upregulated, while 1 protein was consistently downregulated at $>75 \%$ consistency in all of the tested patients. The upregulated proteins were SEC13-like 1 (isoform b) (spot no. 12), calreticulin (spot no. 15), 14-3-3 protein zeta (spot no. 18) and 14-3-3 protein eta (spot no. 19). The downregulated protein was fibrinogen beta chain precursor (spot no. 13). The expression level of these proteins was further verified using Wilcoxon signed-rank test, which determines the statistical significance of the changes in protein expression levels between the two tissues types. The difference in the expression levels of these proteins was statistically 
Table 2

Twenty-four differentially expressed proteins identified

\begin{tabular}{|c|c|c|c|c|c|c|c|c|c|}
\hline $\begin{array}{l}\text { Protein } \\
\text { spot no. }\end{array}$ & $\begin{array}{l}\text { SwissProt } \\
\text { accession } \\
\text { number }\end{array}$ & Protein name & Molecular class & $\begin{array}{c}\text { Molecular } \\
\text { weight }(\mathrm{Da})\end{array}$ & $\mathrm{pI}$ & $\begin{array}{l}\text { GRAVY } \\
\text { score }\end{array}$ & $\begin{array}{l}\text { MOWSE } \\
\text { score }\end{array}$ & $\begin{array}{c}\text { Sequence } \\
\text { coverage }(\%)\end{array}$ & $\begin{array}{l}\text { Average } \\
\text { fold }\end{array}$ \\
\hline 1 & $\mathrm{P} 02768$ & $\begin{array}{l}\text { Serum albumin } \\
\text { precursor }\end{array}$ & Transport/cargo & 71397 & 5.92 & -0.354 & 96 & 14 & +0.382 \\
\hline 2 & P00441 & Superoxide dismutase & Oxidoreductase & 16168 & 5.70 & -0.344 & 52 & 9 & +2.050 \\
\hline 3 & P32119 & Peroxiredoxin-2 & Oxidoreductase & 21935 & 5.67 & -0.199 & 260 & 26 & +3.115 \\
\hline 4 & P00739 & $\begin{array}{l}\text { Haptoglobin-related } \\
\text { precursor }\end{array}$ & Transport/cargo & 39529 & 6.42 & -0.308 & 43 & 3 & -165.850 \\
\hline 5 & P02766 & $\begin{array}{l}\text { Transthyretin } \\
\text { precursor }\end{array}$ & Transport/cargo & 16003 & 5.52 & -0.029 & 75 & 22 & -37.355 \\
\hline 6 & P15090 & $\begin{array}{l}\text { Fatty acid binding } \\
\text { protein }\end{array}$ & Carrier protein & 14704 & 6.81 & -0.249 & 223 & 24 & -905.087 \\
\hline 7 & P00738 & $\begin{array}{l}\text { Haptoglobin precur- } \\
\text { sor, allele } 2 \text { [validated] }\end{array}$ & Transport/cargo & 45901 & 6.13 & -0.421 & 56 & 6 & -0.926 \\
\hline 8 & P02768 & $\begin{array}{l}\text { Serum albumin pre- } \\
\text { cursor [validated] }\end{array}$ & Transport/cargo & 69366 & 5.92 & -0.354 & 46 & 4 & +69.451 \\
\hline 9 & P00739 & $\begin{array}{l}\text { Haptoglobin - related } \\
\text { protein precursor }\end{array}$ & Transport/cargo & 39529 & 6.42 & -0.308 & 55 & 3 & -53.381 \\
\hline 10 & P09211 & $\begin{array}{l}\text { Glutathione } \\
\text { transferase }\end{array}$ & Transferase & 23464 & 5.42 & -0.121 & 277 & 53 & -77.722 \\
\hline 11 & P68371 & $\begin{array}{l}\text { Class IV beta } \\
\text { tubulin }\end{array}$ & Structural protein & 50217 & 4.82 & -0.362 & 52 & 13 & +341.172 \\
\hline 12 & P55735 & $\begin{array}{l}\text { SEC13-like 1, isoform } \\
\text { b }\end{array}$ & Transport/cargo & 36062 & 5.22 & -0.372 & 115 & 37 & +511.402 \\
\hline 13 & P02675 & $\begin{array}{l}\text { Fibrinogen beta chain } \\
\text { precursor }\end{array}$ & Coagulation factor & 56624 & 8.54 & -0.758 & 87 & 28 & -673.998 \\
\hline 14 & P02675 & $\begin{array}{l}\text { Fibrinogen beta chain } \\
\text { precursor }\end{array}$ & Coagulation factor & 56624 & 8.54 & -0.758 & 134 & 31 & -544.111 \\
\hline 15 & P27797 & Calreticulin & Calcium binding protein & 47092 & 4.30 & -1.104 & 107 & 29 & +4750.467 \\
\hline 16 & Not available & Unidentified protein & N/A & N/A & N/A & N/A & N/A & N/A & +706.778 \\
\hline 17 & Q63610 & Hypothetical protein & Hypothetical protein & 27407 & 4.71 & -0.992 & 59 & 27 & +1314.580 \\
\hline 18 & P63104 & $\begin{array}{l}\text { 14-3-3 protein zeta } \\
\text { (kinase regulator) }\end{array}$ & Adaptor molecule & 27745 & 4.73 & -0.621 & 193 & 47 & +1019.138 \\
\hline 19 & Q04917 & $14-3-3$ protein eta & Adaptor molecule & 28244 & 4.76 & -0.618 & 71 & 23 & +2192.104 \\
\hline 20 & P52907 & $\begin{array}{l}\text { F-actin capping } \\
\text { protein }\end{array}$ & Cytoskeletal protein & 32965 & 5.45 & -0.668 & 53 & 26 & -46.854 \\
\hline 21 & P02766 & $\begin{array}{l}\text { Transthyretin } \\
\text { precursor }\end{array}$ & Transport/cargo & 16003 & 5.52 & -0.029 & 85 & 22 & +709.938 \\
\hline 22 & P68133 & Actin alpha & Cytoskeletal protein & 38172 & 5.39 & -0.161 & 64 & 17 & -549.096 \\
\hline 23 & P07195 & $\begin{array}{l}\text { L-lactate } \\
\text { dehydrogenase }\end{array}$ & Dehydrogenase & 36928 & 5.71 & 0.056 & 222 & 34 & +0.314 \\
\hline 24 & P21695 & $\begin{array}{l}\text { Glycerol-3-phosphate } \\
\text { dehydrogenase }\end{array}$ & Dehydrogenase & 38206 & 5.81 & 0.106 & 312 & 51 & -3.292 \\
\hline
\end{tabular}

Table 3

Mean number of spots and standard deviation, percent correlation variation of spots and overall mean of $\mathrm{CV}$ for all, Chinese, Malay and Indian patients

\begin{tabular}{lccc}
\hline Gel group & Mean no. of spots and SD & \%CV of spots & Overall mean of CV \\
\hline All & $508.75 \pm 198.30$ & 38.97 & 67.88 \\
Chinese & $467.94 \pm 175.91$ & 37.59 & 64.98 \\
Malay & $572.67 \pm 245.17$ & 42.81 & 73.13 \\
Indian & $494.90 \pm 157.52$ & 31.86 & 58.54 \\
\hline
\end{tabular}

significant with a $95 \%$ confidence level $(p<0.05)$. We observed variable protein expression amongst the cancer tissues; a protein that was upregulated in one patient could be downregulated, not expressed or equally expressed in the other patient. The inconsistent expres- sion of the spots is shown in Table 4, where each protein spot is presented with a high standard deviation. Figure 3 and Table 5 show the percentage of upregulation, equal expression, downregulation and non-expression of the proteins in all patients. 
Table 4

Mean intensity of protein spots, the standard deviation and percent correlation of variation for spot intensity for all 24 protein spots

\begin{tabular}{ccr}
\hline Protein spot no. & Mean intensity of spots and SD & \%CV of spot intensity \\
\hline 1 & $1608.34 \pm 1096.78$ & 68.19 \\
2 & $5048.73 \pm 3085.41$ & 61.11 \\
3 & $1959.55 \pm 1611.91$ & 82.26 \\
4 & $1275.96 \pm 1320.48$ & 103.49 \\
5 & $3808.45 \pm 3502.47$ & 91.97 \\
6 & $4146.39 \pm 5558.64$ & 134.06 \\
7 & $4343.25 \pm 2970.84$ & 68.40 \\
8 & $448.02 \pm 362.09$ & 80.82 \\
9 & $846.65 \pm 869.82$ & 102.74 \\
10 & $894.49 \pm 1067.33$ & 119.32 \\
11 & $345.38 \pm 451.80$ & 130.82 \\
12 & $333.68 \pm 413.86$ & 124.03 \\
13 & $2110.96 \pm 2230.92$ & 105.68 \\
14 & $2506.71 \pm 2495.17$ & 99.54 \\
15 & $2970.95 \pm 3445.59$ & 115.98 \\
16 & $438.21 \pm 756.14$ & 172.55 \\
17 & $439.92 \pm 708.62$ & 161.08 \\
18 & $1262.42 \pm 2020.47$ & 160.05 \\
19 & $1358.73 \pm 1925.98$ & 141.75 \\
20 & $1327.53 \pm 1148.74$ & 86.53 \\
21 & $1067.94 \pm 1637.22$ & 153.31 \\
22 & $1770.41 \pm 1388.06$ & 78.40 \\
23 & $1905.30 \pm 1032.25$ & 54.18 \\
24 & $946.84 \pm 844.68$ & 89.21 \\
\hline
\end{tabular}

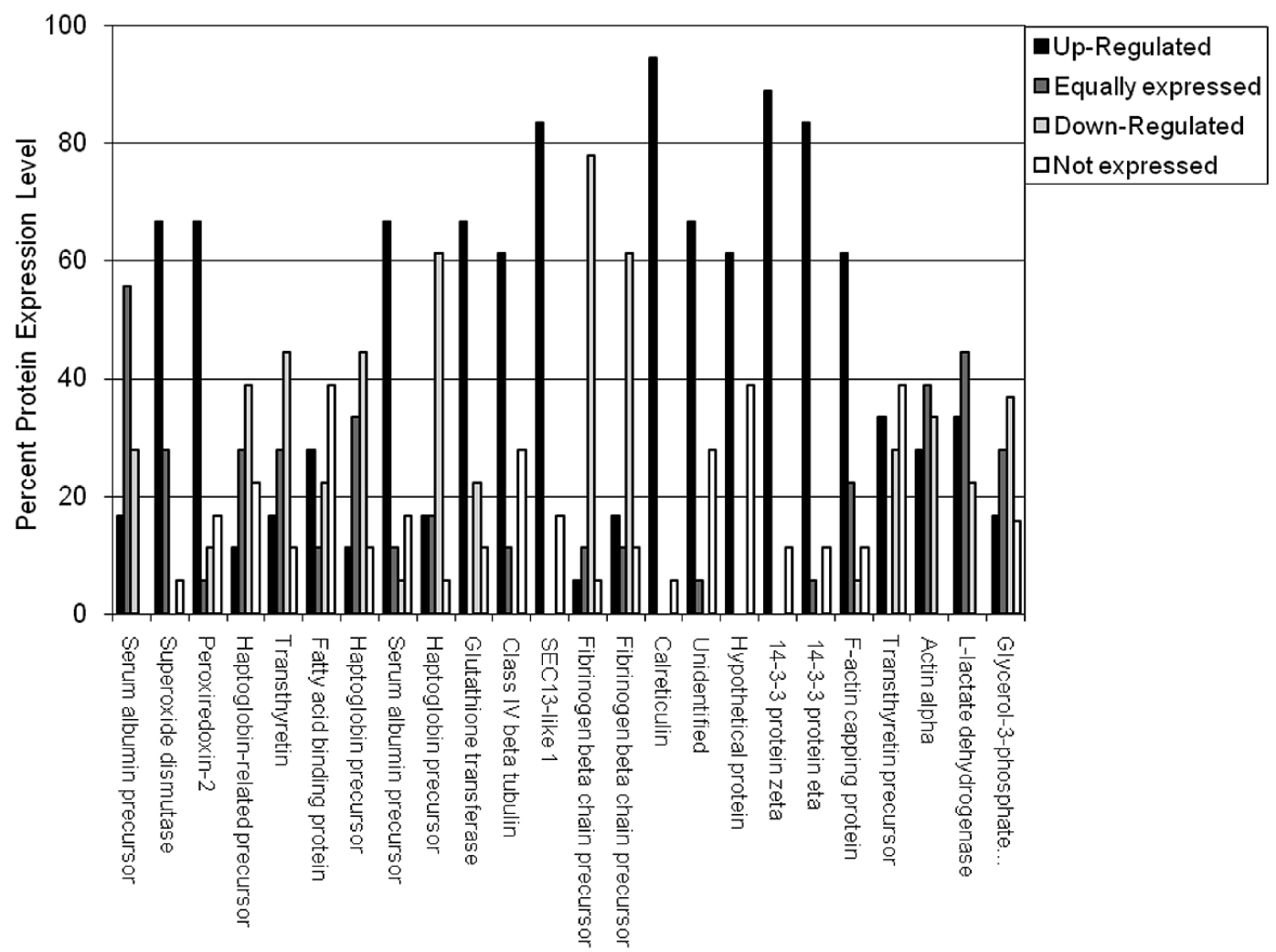

Fig. 3. Distribution of proteins in the cancerous tissues versus normal tissues in the Tris extracts of all patients. An upregulated protein is a protein with a higher expression level in the cancerous tissues than in the normal tissues; the opposite is true for the downregulated proteins. 
Table 5

Percentage and portion of upregulated, same intensity, downregulated and not expressed for all patients

\begin{tabular}{|c|c|c|c|c|c|c|c|c|}
\hline \multirow[t]{2}{*}{ Protein spot } & \multicolumn{2}{|c|}{ Upregulated } & \multicolumn{2}{|c|}{ Same intensity } & \multicolumn{2}{|c|}{ Down-regulated } & \multicolumn{2}{|c|}{ Not expressed } \\
\hline & $\%$ & Portion & $\%$ & portion & $\%$ & portion & $\%$ & portion \\
\hline 1 & 17 & $3 / 18$ & 56 & $10 / 18$ & 28 & $5 / 18$ & 0 & $0 / 18$ \\
\hline 2 & 67 & $12 / 18$ & 28 & $5 / 18$ & 0 & $0 / 18$ & 6 & $1 / 18$ \\
\hline 3 & 67 & $12 / 18$ & 6 & $1 / 18$ & 11 & $2 / 18$ & 17 & $3 / 18$ \\
\hline 4 & 11 & $2 / 18$ & 28 & $5 / 18$ & 39 & $7 / 18$ & 22 & $4 / 18$ \\
\hline 5 & 17 & $3 / 18$ & 28 & $5 / 18$ & 44 & $8 / 18$ & 11 & $2 / 18$ \\
\hline 6 & 28 & $5 / 18$ & 11 & $2 / 18$ & 22 & $4 / 18$ & 39 & $7 / 18$ \\
\hline 7 & 11 & $2 / 18$ & 33 & $6 / 18$ & 44 & $8 / 18$ & 11 & $2 / 18$ \\
\hline 8 & 67 & $12 / 18$ & 6 & $2 / 18$ & 6 & $1 / 18$ & 17 & $3 / 18$ \\
\hline 9 & 17 & $3 / 18$ & 17 & $3 / 18$ & 61 & $11 / 18$ & 6 & $1 / 18$ \\
\hline 10 & 67 & $12 / 18$ & 0 & $0 / 18$ & 22 & $4 / 18$ & 11 & $2 / 18$ \\
\hline 11 & 61 & $11 / 18$ & 11 & $2 / 18$ & 0 & $0 / 18$ & 28 & $5 / 18$ \\
\hline 12 & 83 & $15 / 18$ & 0 & $0 / 18$ & 0 & $0 / 18$ & 17 & $3 / 18$ \\
\hline 13 & 6 & $1 / 18$ & 11 & $2 / 18$ & 78 & $14 / 18$ & 6 & $1 / 18$ \\
\hline 14 & 17 & $3 / 18$ & 11 & $2 / 18$ & 61 & $11 / 18$ & 11 & $2 / 18$ \\
\hline 15 & 94 & $17 / 18$ & 0 & $0 / 18$ & 0 & $0 / 18$ & 6 & $1 / 18$ \\
\hline 16 & 67 & $12 / 18$ & 6 & $1 / 18$ & 0 & $0 / 18$ & 28 & $5 / 18$ \\
\hline 17 & 61 & $11 / 18$ & 0 & $0 / 18$ & 0 & $0 / 18$ & 39 & $7 / 18$ \\
\hline 18 & 89 & $16 / 18$ & 0 & $0 / 18$ & 0 & $0 / 18$ & 11 & $2 / 18$ \\
\hline 19 & 83 & $15 / 18$ & 6 & $1 / 18$ & 0 & $0 / 18$ & 11 & $2 / 18$ \\
\hline 20 & 61 & $11 / 18$ & 22 & $4 / 18$ & 6 & $1 / 18$ & 11 & $2 / 18$ \\
\hline 21 & 33 & $6 / 18$ & 0 & $0 / 18$ & 28 & $5 / 18$ & 39 & $7 / 18$ \\
\hline 22 & 28 & $5 / 18$ & 39 & $7 / 18$ & 33 & $6 / 18$ & 0 & $0 / 18$ \\
\hline 23 & 33 & $6 / 18$ & 44 & $8 / 18$ & 22 & $4 / 18$ & 0 & $0 / 18$ \\
\hline 24 & 17 & $3 / 18$ & 28 & $5 / 18$ & 39 & $7 / 18$ & 17 & $3 / 18$ \\
\hline
\end{tabular}

In Chinese patients $(n=8)$, the consistent expression $(>75 \%)$ of 5 upregulated proteins and 1 downregulated protein was detected. The upregulated proteins were serum superoxide dismutase, glutathione transferase, calreticulin, 14-3-3 protein zeta and 14-3-3 protein eta. The downregulated protein was fibrinogen beta chain precursor. Changes in the expressions levels of all of the proteins listed above were statistically significant at the 95\% confidence level ( $\mathrm{p}<0.05)$, except for the expression level of glutathione transferase, which was not statistically significant $(p=0.05)$. Table 6 shows the percentage of upregulation, equal expression, downregulation and non-expression of the proteins in Chinese patients.

In Malay patients $(n=8)$, the consistent expression $(>75 \%)$ of 10 upregulated proteins and 2 downregulated proteins was detected. The upregulated proteins were peroxiredoxin-2, serum albumin precursor, class IV beta tubulin, SEC13-like 1 (isoform b), calreticulin, unidentified protein (spot 16), hypothetical protein, 14-3-3 protein zeta, 14-3-3 protein eta and F-actin capping protein. The downregulated proteins were fibrinogen beta chain precursor and haptoglobin-related protein precursor. Table 7 shows the percentage of upregulation, equal expression, downregulation and nonexpression of the proteins in Malay patients. Changes in the expressions levels of all the proteins listed above were statistically significant $(p<0.05)$ except class IV beta-tubulin, which was not statistically significant $(p=0.05)$. The upregulation of calreticulin in Chinese and Malay patients was further confirmed by the Western blotting experiment shown in Fig. 4.

In Indian patients $(n=4)$, the consistent expression (>75\%) of 4 upregulated proteins and 2 downregulated proteins was detected. The upregulated proteins were SEC-like 1 (isoform b), calreticulin, 14-3-3 protein zeta and 14-3-3 protein eta. The downregulated proteins were fibrinogen beta chain precursor and haptoglobin precursor (allele 2). Table 8 shows the percentage of upregulation, equally expressed, downregulation and non-expression of the proteins in Indian patients. Since there were only 4 Indian patients, the Wilcoxon signedrank test could not be performed, and therefore, the statistical significance of the data was not determined.

The expression levels of 12 proteins were significantly upregulated in at least one of the ethnic groups. Figure 5 shows the upregulation of these proteins in the Chinese, Malay and Indian patients and in all the patients tested. Superoxide dismutase was upregulated in $75 \%$ of Chinese patients. However, it was upregulated in only $67 \%$ of all patients and Malay patients, and only $50 \%$ in Indian patients. Peroxiredoxin- 2 and 
Table 6

Percentage and portion of upregulated, same intensity, downregulated and not expressed for Chinese patients

\begin{tabular}{|c|c|c|c|c|c|c|c|c|}
\hline \multirow[t]{2}{*}{ Protein spot } & \multicolumn{2}{|c|}{ Upregulated } & \multicolumn{2}{|c|}{ Same intensity } & \multicolumn{2}{|c|}{ Down-regulated } & \multicolumn{2}{|c|}{ Not expressed } \\
\hline & $\%$ & portion & $\%$ & portion & $\%$ & portion & $\%$ & portion \\
\hline 1 & 25 & $2 / 8$ & 38 & $3 / 8$ & 38 & $3 / 8$ & 0 & $0 / 8$ \\
\hline 2 & 75 & $6 / 8$ & 25 & $2 / 8$ & 0 & $0 / 8$ & 0 & $0 / 8$ \\
\hline 3 & 63 & $5 / 8$ & 13 & $1 / 8$ & 0 & $0 / 8$ & 25 & $2 / 8$ \\
\hline 4 & 25 & $2 / 8$ & 25 & $2 / 8$ & 38 & $3 / 8$ & 13 & $1 / 8$ \\
\hline 5 & 25 & $2 / 8$ & 38 & $3 / 8$ & 38 & $3 / 8$ & 0 & $0 / 8$ \\
\hline 6 & 13 & $1 / 8$ & 0 & $0 / 8$ & 38 & $3 / 8$ & 50 & $4 / 8$ \\
\hline 7 & 25 & $2 / 8$ & 38 & $3 / 8$ & 25 & $2 / 8$ & 13 & $1 / 8$ \\
\hline 8 & 63 & $5 / 8$ & 13 & $1 / 8$ & 13 & $1 / 8$ & 13 & $1 / 8$ \\
\hline 9 & 25 & $2 / 8$ & 25 & $2 / 8$ & 50 & $4 / 8$ & 0 & $0 / 8$ \\
\hline 10 & 75 & $6 / 8$ & 0 & $0 / 8$ & 13 & $1 / 8$ & 13 & $1 / 8$ \\
\hline 11 & 63 & $5 / 8$ & 0 & $0 / 8$ & 0 & $0 / 8$ & 38 & $3 / 8$ \\
\hline 12 & 63 & $5 / 8$ & 0 & $0 / 8$ & 0 & $0 / 8$ & 38 & $3 / 8$ \\
\hline 13 & 13 & $1 / 8$ & 0 & $0 / 8$ & 75 & $6 / 8$ & 13 & $1 / 8$ \\
\hline 14 & 38 & $3 / 8$ & 0 & $0 / 8$ & 50 & $4 / 8$ & 13 & $1 / 8$ \\
\hline 15 & 88 & $7 / 8$ & 0 & $0 / 8$ & 0 & $0 / 8$ & 13 & $1 / 8$ \\
\hline 16 & 63 & $5 / 8$ & 0 & $0 / 8$ & 0 & $0 / 8$ & 38 & $3 / 8$ \\
\hline 17 & 63 & $5 / 8$ & 0 & $0 / 8$ & 0 & $0 / 8$ & 38 & $3 / 8$ \\
\hline 18 & 88 & $7 / 8$ & 0 & $0 / 8$ & 0 & $0 / 8$ & 13 & $1 / 8$ \\
\hline 19 & 75 & $6 / 8$ & 13 & $1 / 8$ & 0 & $0 / 8$ & 13 & $1 / 8$ \\
\hline 20 & 63 & $5 / 8$ & 13 & $1 / 8$ & 13 & $1 / 8$ & 13 & $1 / 8$ \\
\hline 21 & 38 & $3 / 8$ & 0 & $0 / 8$ & 25 & $2 / 8$ & 38 & $3 / 8$ \\
\hline 22 & 38 & $3 / 8$ & 50 & $4 / 8$ & 13 & $1 / 8$ & 0 & $0 / 8$ \\
\hline 23 & 38 & $3 / 8$ & 50 & $4 / 8$ & 13 & $1 / 8$ & 0 & $0 / 8$ \\
\hline 24 & 13 & $1 / 8$ & 13 & $1 / 8$ & 50 & $4 / 8$ & 25 & $2 / 8$ \\
\hline
\end{tabular}

Table 7

Percentage and portion of upregulated, same intensity, downregulated and not expressed for Malay patients

\begin{tabular}{|c|c|c|c|c|c|c|c|c|}
\hline \multirow[t]{2}{*}{ Protein spot } & \multicolumn{2}{|c|}{ Upregulated } & \multicolumn{2}{|c|}{ Same intensity } & \multicolumn{2}{|c|}{ Down-regulated } & \multicolumn{2}{|c|}{ Not expressed } \\
\hline & $\%$ & portion & $\%$ & portion & $\%$ & portion & $\%$ & portion \\
\hline 1 & 17 & $1 / 6$ & 67 & $4 / 6$ & 17 & $1 / 6$ & 0 & $0 / 6$ \\
\hline 2 & 67 & $4 / 6$ & 33 & $2 / 6$ & 0 & $0 / 6$ & 0 & $0 / 6$ \\
\hline 3 & 83 & $5 / 6$ & 0 & $0 / 6$ & 17 & $1 / 6$ & 0 & $0 / 6$ \\
\hline 4 & 0 & $0 / 6$ & 33 & $2 / 6$ & 50 & $3 / 6$ & 17 & $1 / 6$ \\
\hline 5 & 17 & $1 / 6$ & 17 & $1 / 6$ & 67 & $4 / 6$ & 0 & $0 / 6$ \\
\hline 6 & 67 & $4 / 6$ & 0 & $0 / 6$ & 17 & $1 / 6$ & 17 & $1 / 6$ \\
\hline 7 & 0 & $0 / 6$ & 33 & $2 / 6$ & 50 & $3 / 6$ & 17 & $1 / 6$ \\
\hline 8 & 83 & $5 / 6$ & 17 & $1 / 6$ & 0 & $0 / 6$ & 0 & $0 / 6$ \\
\hline 9 & 17 & $1 / 6$ & 0 & $0 / 6$ & 83 & $5 / 6$ & 0 & $0 / 6$ \\
\hline 10 & 67 & $4 / 6$ & 0 & $0 / 6$ & 33 & $2 / 6$ & 0 & $0 / 6$ \\
\hline 11 & 83 & $5 / 6$ & 0 & $0 / 6$ & 0 & $0 / 6$ & 17 & $1 / 6$ \\
\hline 12 & 100 & $6 / 6$ & 0 & $0 / 6$ & 0 & $0 / 6$ & 0 & $0 / 6$ \\
\hline 13 & 0 & $0 / 6$ & 17 & $1 / 6$ & 83 & $5 / 6$ & 0 & $0 / 6$ \\
\hline 14 & 0 & $0 / 6$ & 17 & $1 / 6$ & 83 & $5 / 6$ & 0 & $0 / 6$ \\
\hline 15 & 100 & $6 / 6$ & 0 & $0 / 6$ & 0 & $0 / 6$ & 0 & $0 / 6$ \\
\hline 16 & 83 & $5 / 6$ & 17 & $1 / 6$ & 0 & $0 / 6$ & 0 & $0 / 6$ \\
\hline 17 & 83 & $5 / 6$ & 0 & $0 / 6$ & 0 & $0 / 6$ & 17 & $1 / 6$ \\
\hline 18 & 100 & $6 / 6$ & 0 & $0 / 6$ & 0 & $0 / 6$ & 0 & $0 / 6$ \\
\hline 19 & 100 & $6 / 6$ & 0 & $0 / 6$ & 0 & $0 / 6$ & 0 & $0 / 6$ \\
\hline 20 & 83 & $5 / 6$ & 17 & $1 / 6$ & 0 & $0 / 6$ & 0 & $0 / 6$ \\
\hline 21 & 33 & $2 / 6$ & 0 & $0 / 6$ & 33 & $2 / 6$ & 33 & $2 / 6$ \\
\hline 22 & 33 & $2 / 6$ & 33 & $2 / 6$ & 33 & $2 / 6$ & 0 & $0 / 6$ \\
\hline 23 & 33 & $2 / 6$ & 33 & $2 / 6$ & 33 & $2 / 6$ & 0 & $0 / 6$ \\
\hline 24 & 17 & $1 / 6$ & 50 & $3 / 6$ & 33 & $2 / 6$ & 0 & $0 / 6$ \\
\hline
\end{tabular}


Table 8

Percentage and portion of upregulated, same intensity, downregulated and not expressed for Indian patients

\begin{tabular}{|c|c|c|c|c|c|c|c|c|}
\hline \multirow[t]{2}{*}{ Protein spot } & \multicolumn{2}{|c|}{ Upregulated } & \multicolumn{2}{|c|}{ Same intensity } & \multicolumn{2}{|c|}{ Down-regulated } & \multicolumn{2}{|c|}{ Not expressed } \\
\hline & $\%$ & portion & $\%$ & portion & $\%$ & portion & $\%$ & portion \\
\hline 1 & 0 & $0 / 4$ & 75 & $3 / 4$ & 25 & $1 / 4$ & 0 & $0 / 4$ \\
\hline 2 & 50 & $2 / 4$ & 25 & $1 / 4$ & 0 & $0 / 4$ & 25 & $1 / 4$ \\
\hline 3 & 50 & $2 / 4$ & 0 & $0 / 4$ & 25 & $1 / 4$ & 25 & $1 / 4$ \\
\hline 4 & 0 & $0 / 4$ & 25 & $1 / 4$ & 25 & $1 / 4$ & 50 & $2 / 4$ \\
\hline 5 & 0 & $0 / 4$ & 25 & $1 / 4$ & 25 & $1 / 4$ & 50 & $2 / 4$ \\
\hline 6 & 0 & $0 / 4$ & 50 & $2 / 4$ & 0 & $0 / 4$ & 50 & $2 / 4$ \\
\hline 7 & 0 & $0 / 4$ & 25 & $1 / 4$ & 75 & $3 / 4$ & 0 & $0 / 4$ \\
\hline 8 & 50 & $2 / 4$ & 0 & $0 / 4$ & 0 & $0 / 4$ & 50 & $2 / 4$ \\
\hline 9 & 0 & $0 / 4$ & 25 & $1 / 4$ & 50 & $2 / 4$ & 25 & $1 / 4$ \\
\hline 10 & 50 & $2 / 4$ & 0 & $0 / 4$ & 25 & $1 / 4$ & 25 & $1 / 4$ \\
\hline 11 & 25 & $1 / 4$ & 50 & $2 / 4$ & 0 & $0 / 4$ & 25 & $1 / 4$ \\
\hline 12 & 100 & $4 / 4$ & 0 & $0 / 4$ & 0 & $0 / 4$ & 0 & $0 / 4$ \\
\hline 13 & 0 & $0 / 4$ & 25 & $1 / 4$ & 75 & $3 / 4$ & 0 & $0 / 4$ \\
\hline 14 & 0 & $0 / 4$ & 25 & $1 / 4$ & 50 & $2 / 4$ & 25 & $1 / 4$ \\
\hline 15 & 100 & $4 / 4$ & 0 & $0 / 4$ & 0 & $0 / 4$ & 0 & $0 / 4$ \\
\hline 16 & 50 & $2 / 4$ & 0 & $0 / 4$ & 0 & $0 / 4$ & 50 & $2 / 4$ \\
\hline 17 & 50 & $2 / 4$ & 0 & $0 / 4$ & 0 & $0 / 4$ & 50 & $2 / 4$ \\
\hline 18 & 75 & $3 / 4$ & 0 & $0 / 4$ & 0 & $0 / 4$ & 25 & $1 / 4$ \\
\hline 19 & 75 & $3 / 4$ & 0 & $0 / 4$ & 0 & $0 / 4$ & 25 & $1 / 4$ \\
\hline 20 & 25 & $1 / 4$ & 50 & $2 / 4$ & 0 & $0 / 4$ & 25 & $1 / 4$ \\
\hline 21 & 25 & $1 / 4$ & 0 & $0 / 4$ & 25 & $1 / 4$ & 50 & $2 / 4$ \\
\hline 22 & 50 & $2 / 4$ & 50 & $2 / 4$ & 0 & $0 / 4$ & 0 & $0 / 4$ \\
\hline 23 & 25 & $1 / 4$ & 50 & $2 / 4$ & 25 & $1 / 4$ & 0 & $0 / 4$ \\
\hline 24 & 25 & $1 / 4$ & 25 & $1 / 4$ & 25 & $1 / 4$ & 25 & $1 / 4$ \\
\hline
\end{tabular}

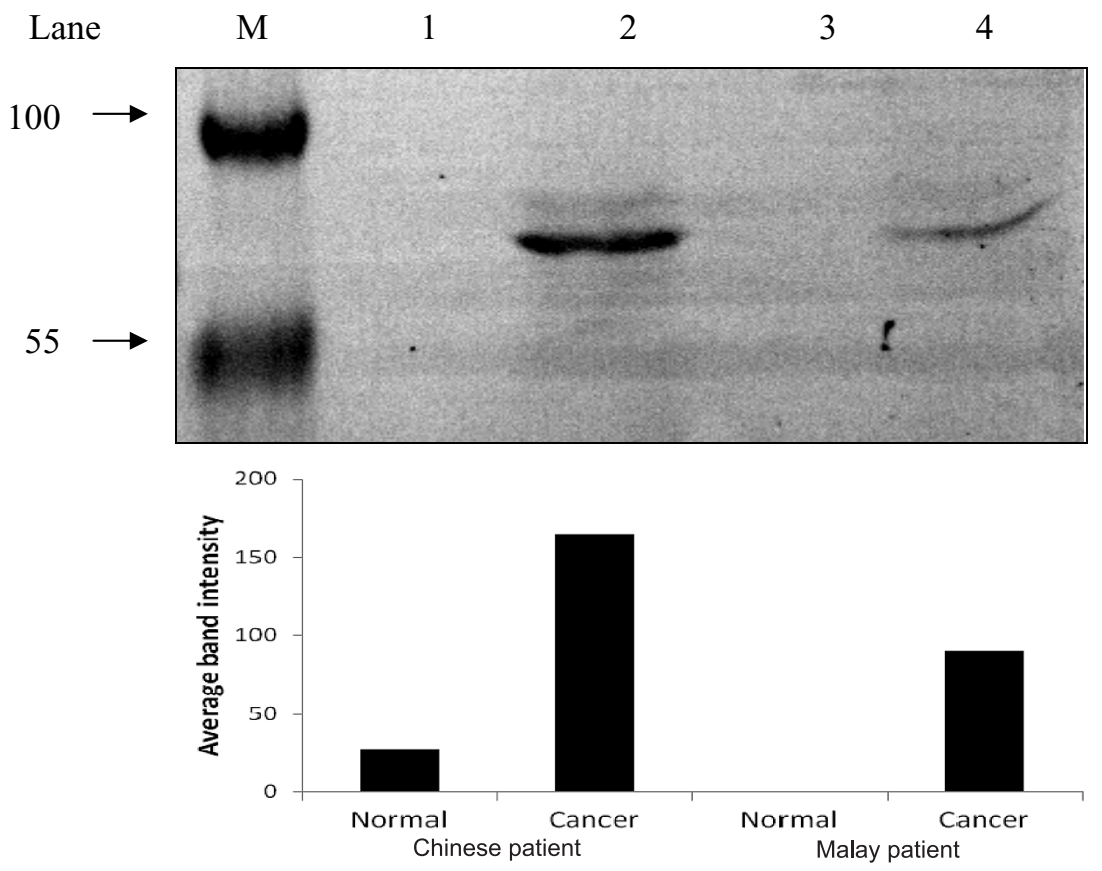

Fig. 4. Immunoblot of calreticulin. Lane M: Protein molecular weight markers (in kDa). Lane 1: Normal tissue of a Chinese patient. Lane 2: Cancerous tissue from the same Chinese patient. Lane 3: Normal tissue of a Malay patient. Lane 4: Cancerous tissue from the same Malay patient. 


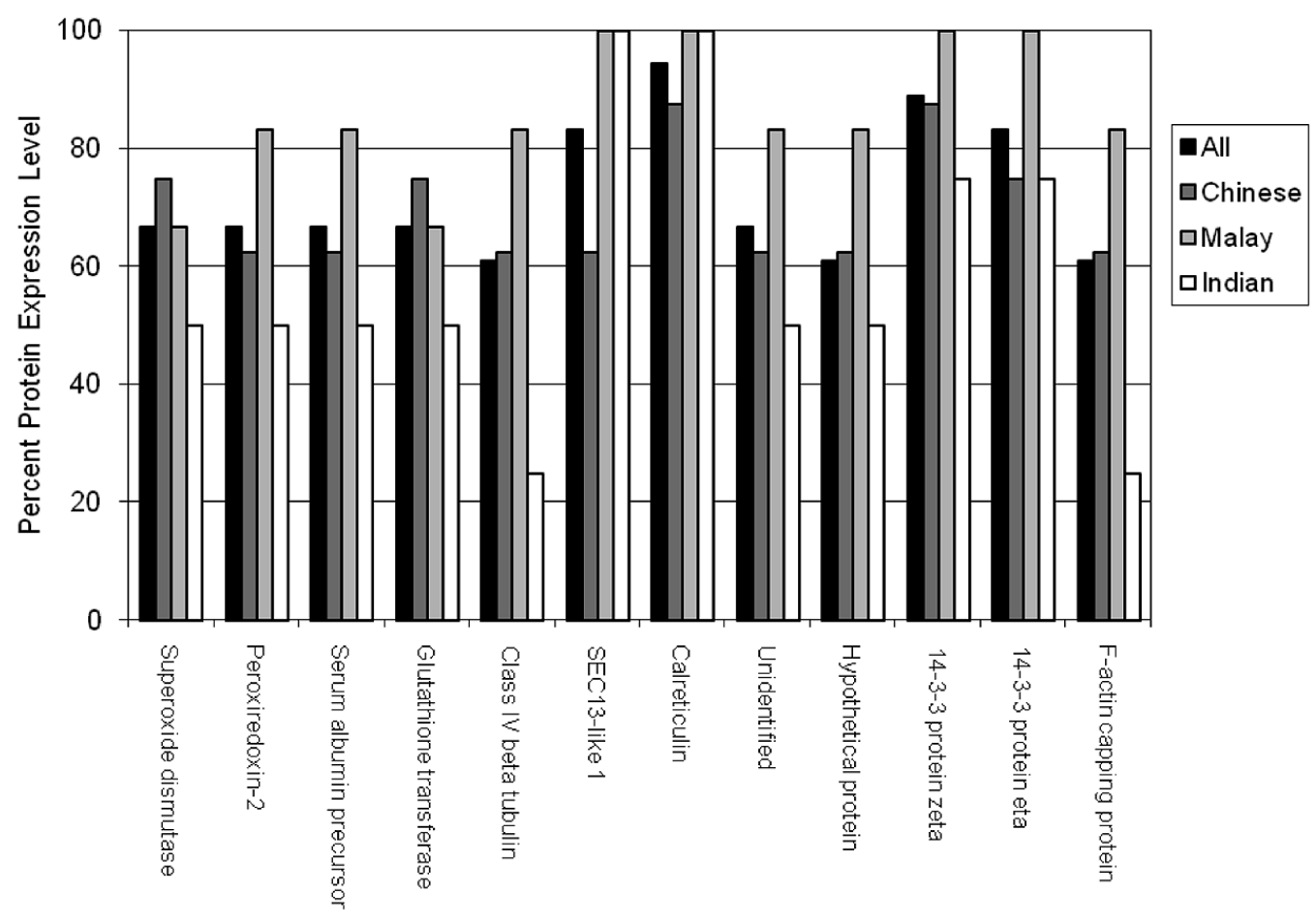

Fig. 5. Comparison of the upregulated proteins in all three races.

serum albumin precursor were upregulated in $83 \%$ of Malay patients. Both of these proteins were upregulated in $67 \%, 63 \%$ and $50 \%$ in all, Chinese and Indian patients, respectively. Glutathione transferase was upregulated in $75 \%$ of Chinese patients, in $67 \%$ of all patients and Malay patients and in only $50 \%$ of Indian patients. Class IV beta-tubulin was upregulated in $83 \%$ of Malay patients. However, its upregulation in all, Chinese and Indian patients was only $61 \%, 63 \%$ and $25 \%$, respectively. SEC13-like 1 was upregulated in $83 \%$ of all patients and $100 \%$ of both Malay and Indian patients. However, it was only upregulated in $63 \%$ of Chinese patients. Calreticulin was upregulated in $94 \%, 88 \%, 100 \%$ and $100 \%$ in all, Chinese, Malay and Indian patients, respectively. The unidentified protein (protein spot 16) was upregulated in $83 \%$ of Malay patients, but it was only upregulated in $67 \%, 63 \%$ and $50 \%$ of all, Chinese and Indian patients, respectively. Similarly, the hypothetical protein was upregulated in $83 \%$ of Malay patients, but it was only upregulated in $61 \%, 63 \%$ and $50 \%$ of all, Chinese and Indian patients, respectively. 14-3-3 protein zeta was upregulated in all ethnic groups. The protein was upregulated in $89 \%$, $88 \%, 100 \%$ and $75 \%$ of all, Chinese, Malay and Indian patients, respectively. 14-3-3 protein eta also was upregulated in all ethnic groups. The protein was up- regulated in $83 \% 75 \%, 100 \%$ and $75 \%$ of all, Chinese, Malay and Indian patients, respectively. F-actin capping protein was upregulated in $83 \%$ of Malay patients. However, it was only upregulated in $61 \%, 63 \%$ and $25 \%$ of all, Chinese and Indian patients, respectively. In this study, we found no co-relationship between the expression of the protein we identified and the expression of estrogen receptor, progesterone receptor, C-ERB-B ${ }_{2}$ oncoprotein, triple negative or non-triple negative (Supplement al Data).

\section{Discussion}

Underlying changes in protein expression between normal and cancerous tissue are expected in the development of cancer. In this study, surgically removed cancerous and normal breast tissues specimens were used in the analysis. Therefore, the data obtained reveal actual changes in protein expression between normal and cancerous cells. A pair-wise comparison of normal and cancerous tissues from the same patient and a cross-comparison between the cancerous and normal tissues of all the patients were carried out in order to identify differentially expressed proteins. We did not identify any protein that could be used as the sole mark- 
er to indicate breast cancer, due to the variable expression of proteins between the patients; an upregulated protein in one patient may be downregulated in another and not expressed in the third. This observation demonstrates the complexity of protein interactions in cancer development, which makes it one of the incurable diseases or a disease that cannot be cured by a single remedy. Therefore, we targeted only the proteins that show great consistency in their expression levels in most of the patients. We believe that this approach minimises the identification of false positive proteins resulting from tissue heterogeneity between individuals or sample handling.

The correlation between the identified markers and the tissue subtypes, namely estrogen receptor, progesterone receptor, $\mathrm{C}-\mathrm{ERB}-\mathrm{B}_{2}$ oncoprotein, triple negative, non-triple negative, which are used to indicate the prognosis of patients, was evaluated. Upregulation of the markers was well distributed in all tissues subtypes between the cohorts (Supplement 1) and within the same ethnic cohort (Supplement 2), and hence no correlation between the markers and the tissue subtypes could be established. We noticed that the expression of the proteins was more consistent when the patients were grouped according to their ethnicity, Chinese, Malay and Indian, regardless of the tissue subtypes (Supplemental Data).

In this study, four proteins were found to be significantly and consistently upregulated in $>75 \%$ of all patients tested. These proteins were SEC13-like 1 (83\%), calreticulin $(94 \%), 14-3-3$ protein zeta $(89 \%)$ and $14-$ 3-3 protein eta $(83 \%)$. The high expression levels of these proteins in all of the patients were strongly influenced by the Malay patients; all four of the proteins were found to be consistently upregulated (100\%) in all of the Malay patients tested. Additionally, SEC13-like 1 and calreticulin were also upregulated in all of the Indian patients (100\%) tested. Calreticulin was one of the two upregulated proteins found in $88 \%$ of the Chinese patients. The other protein that was significant in Chinese patients was $14-3-3$ protein zeta (88\%). Other proteins that were found to be expressed at $>75 \%$ consistency in Malay patients included peroxiredoxin$2(83 \%)$, serum albumin precursor $(83 \%)$, unidentified spot 16 protein $(83 \%)$, a hypothetical protein $(83 \%), \mathrm{F}-$ actin capping protein $(83 \%)$ and class IV beta-tubulin $(83 \%)$.

The expression of calreticulin, 14-3-3 protein zeta and 14-3-3 protein eta in breast cancer was more significant than the other proteins found in this study. The expression levels of these proteins in cancerous tissues were consistently high in patients with breast cancer, regardless of race. Although SEC13-like 1 was detected in $100 \%$ of the Malay and Indian patients, it was upregulated in only $63 \%$ of the Chinese patients tested. As for other proteins, their expression varied greatly between the ethnic groups.

Calreticulin is an abundant, multifunctional and high-capacity calcium ion binding protein that regulates cellular activities in the endoplasmic reticulum [31]. It binds to misfolded proteins and prevents the transportation of these proteins to the Golgi apparatus. Our results for the expression of calreticulin are in agreement with other researchers whose studies were conducted in Caucasian patients [32-34].

14-3-3 eta protein (YWAH) and 14-3-3 zeta protein (YWAZ) are subunits of the 14-3-3 isoform proteins (14-3-3), which are conserved regulatory proteins that bind to proteins involved in the signaling pathway, including kinases, phosphatases and transmembrane receptors. 14-3-3 proteins also interact with the signalling proteins to mediate a wide variety of cellular events such as cell cycle regulation, cell growth, cell differentiation, cell survival, anti-apoptosis and synaptic transmission [35-39]. 14-3-3 proteins regulate processes that are important in cancer biology; they inhibit apoptosis, act as cell cycle checkpoints $[40,41]$ and mediating oncogene products that are over-expressed in cancer cells [42]. 14-3-3 proteins are upregulated in highly metastatic variants of breast cancer cell lines [18] and in tumour cells in breast ductal carcinoma [43].

Protein SEC13 homologue (SEC13) is a mammalian protein that belongs to the SEC13 family of WD-repeat proteins. It has similarity to the yeast SEC13 protein, which is required for vesicle biogenesis from the endoplasmic reticulum during the transport of proteins. Since studies have supported the theory that the molecular function of SEC13 is conserved from yeast to humans, it is conceivable that the human SEC13 protein may be involved in intracellular protein transport as well $[44,45]$. The human SEC13 protein is a putative component of the coatomer (COPI) complex, a protein complex that mediates the budding of vesicles. Since COPI is similar to the yeast COPII system, it is thought that COPI and therefore human SEC13 protein play a role in transporting proteins via the budding of vesicles from the endoplasmic reticulum to the Golgi apparatus [46]. Its involvement in cancer has not been reported.

All patients involved in this study are from the northern region of Malaysia. Nevertheless, due to the difference in ethnicity, they do not share a similar lifestyle, 
including the types of foods consumed. The Malaysian Chinese and Malay populations probably have a closer genetic make-up as compared to the Indian population, since the former originated from China-Mongolia while the latter was from India [47]. The data obtained in this study showed that the Malay population had greater consistency in terms of the expression of proteins between the patients, whereby the number of proteins expressed at $>75 \%$ was much higher when compared to other ethnic groups.

The expression of protein in cancer may be defined more precisely according to the menopausal status of the patient and the stage and grade of the cancer. Nevertheless, although the analysis of protein expression was carried solely based on the race of the patients, we detected a high level of consistency in the expression of certain ethnic-specific biomarkers in this study. The data reveal that despite the changes that are expected to take place during the progression of cancer, the expression of protein in cancerous tissues is still largely influenced by the genetic make-up of individual patients, that as we have shown in this study, is ethnicity-oriented. For this reason, the development of ethnic-specific drug-targeted therapy may be feasible.

\section{Conclusion}

Although sample size is a limiting factor in our study, the data demonstrate the possible correlation between protein expression and the ethnicity of the patient. The differential expression of proteins between ethnic groups may explain the different efficacy of anticancer drugs, which has previously been shown to be race-specific [48]. By organising protein profile maps according to ethnicity, proteins that are more prevalent in a specific ethnic group can be determined, and therefore ethnic-specific diagnoses as well as drug design are possible to be formulated for more effective usage.

\section{Supplementary material}

Supplementary data can be found on http://www.pha. usm.my/pharmacy/Gam.html.

\section{Acknowledgments}

We thank the Ministry of Science, Technology and Innovation, Malaysia for providing the grant (Project number: 02-01-05-SF0353) to fund this project; the
National Institute of Pharmaceutical and Nutraceutical, the Ministry of Science, Technology and Innovation, Malaysia for the use of the mass spectrometry instrument to analyse proteins and the Ministry of Health, Malaysia for providing the tissue samples and the human ethical clearance for conducting this research. Written consent for publication was obtained from the patient or a relative.

\section{References}

[1] American Cancer Society, How many women get breast cancer? [updated 26th September 2006, Online], 2006, Available from: http://www.cancer.org/docroot/CRI/content/CRL 2.2 1X_How_many_people_get_breast_cancer_5.asp.

[2] World Health Organization, Cancer: Fact Sheet, [updated July 2008, Online], 2008, Available from: http://www.who.int/ entity/mediacentre/factsheets/fs297/en/index.html.

[3] L.A.G. Ries, D. Malbert, M. Krapcho, D.G. Stinchcomb, N. Howlader, M.J. Horner, A. Mariotto, B.A. Miller, E.J. Feuer, S.F. Altekruse, D.R. Lewis, L. Clegg, M.P. Eisner, M. Reichman and B.K. Edwards, SEER Cancer Statistics Review, 1975-2005, National Cancer Institute, Marylan Bethesda, 2008.

[4] G.C.C. Lim and Y. Halimah, Second report of the National Cancer Registry 2003: Cancer incidence in Malaysia 2003, National Cancer Registry, Kuala Lumpur (2004), 36.

[5] Malaysian Oncological Society (2007) Breast cancer. [Online] Available from World Wide Web: http://www.malaysiao ncology.org/article.php?aid=114 [Accessed: 30th July 2007].

[6] R.B. Dickson, R.G. Pestell and M.E. Lippman, Cancer of the breast, in: Cancer - Principals and practice of oncology, V.T. Devita and S.A. Rosenberg, eds, Lippincott Williams and Wilkins, Philadelphia, 2005, pp. 1399-1487.

[7] National Cancer Institute (2004) Tumor grade: Questions and answers. [Online] (Posted 19th May 2004). Available from World Wide Web: http://www.cancer.gov/cancertopics/ factsheet/Detection/tumor-grade, Accessed:30th March 2008.

[8] National Cancer Institute (2007) Breast cancer staging. [Online] (Posted 1st November 2007). Available from World Wide Web: http://www.cancer.gov/cancertopics/wyntk/breast/page 9 [Accessed: 30th March 2008].

[9] H.M. Zhang, L.X. Xuan, J.D. Gao, B.N. Zhang and P. Zhao, Clinical characteristics comparison between triple-negative and non-triple negative breast cancer, Zhonghua Wai Ke Za Zhi 47 (2009), 506-510.

[10] C.H. Yip, N.A. Taib, W.Y. Choo, S. Rampal, M.K. Thong and S.H. Teo, Clinical and pathologic differences between BRCA1-, BRCA2-, and non-BRCA-associated breast cancers in a multiracial developing country, World J Surg, in print.

[11] B.K. Tan, G.H. Lim, K, Czene, P. Hall and K.S. Chia, Do Asian breast cancer patients have poorer survival than their western counterparts? A comparison between Singapore and Stockholm, Breast Cancer Res 11 (2009), R4.

[12] R.K. Rasmussen, H. Ji, J.S. Eddes, R.L. Mortiz, G.E. Reid, R.J. Simpson and D.S. Dorow, Two-dimensional electrophoretic analysis of human breast carcinoma proteins: Mapping of proteins that bind to the SH3 domain of mixed lineage kinase MLK2, Electrophoresis 18 (1997), 588-598. 
[13] M.R. Wilkins, C. Pasquali, R.D. Appel, K. Ou, O. Golaz, J.C. Sanchez, J.X. Yan, A.A. Gooley, G. Hughes, I. HumphreySmith, K.L. Williams and D.F. Hochstrasser, From protein to proteomics: Large-scale protein identification by twodimensional electrophoresis and amino acid analysis, Biotechnology 14 (1996), 61-65.

[14] P.H. O'Farrell, High resolution two-dimensional electrophoresis of proteins, J Biol Chem 250 (1975), 4007-4021.

[15] M. Mann and G. Talbo, Developments in matrix-assisted laser desorption/ionization peptide mass spectrometry, Curr Opin Biotechnol 7 (1996), 11-19.

[16] C.S. Giometti, S.L. Tollaksen, C. Chubb, C. Williams and E. Huberman, Analysis of proteins from human breast epithelial cells using two-dimensional gel electrophoresis, Electrophoresis 16 (1995), 1215-1524.

[17] F. Le Naour, D.E. Misek, M.C. Krause, L. Deneux, T.J. Giordano, S. Scholl and S.M. Hamash, Proteomics-based identification of RS/DJ-1 as a novel circulating tumour antigen in breast cancer, Clin Cancer Res 7 (2001), 3325-3327.

[18] D.Q. Li, L. Wang, F. Fei, Y.F. Hou, J.M. Luo, Wei-Chen, R. Zeng, J. Wu, J.S. Lu, G.H. Di, Z.L. Ou, Q.C. Xia, Z.Z. Shen and Z.M. Shao, Identification of breast cancer metastasis-associated proteins in an isogenic tumor metastasis model using two-dimensional gel electrophoresis and liquid chromatography-ion trap mass spectrometry, Proteomics 6 (2006), 3352-3368.

[19] M.J. Page, B. Amess, R.R. Townsend, R. Parekh, A. Herath, L. Brusten, M.J. Zvelebil, R.C. Stein, M.D. Waterfield, S.C. Davies and M.J. O'Hare, Proteomic definition of normal human luminal and myoepithelial breast cells purified from reduction mammoplasties, Proc Natl Acad Sci USA 96 (1999), 12589-12594.

[20] K. Williams, C. Chubb, E. Hubermann and C.S. Giometti, Analysis of differential protein expression in normal and neoplastic human breast epithelial cell lines, Electrophoresis 19 (1998), 333-343.

[21] P. Alfonso, A. Nuñez, J. Madoz-Gurpide, L. Lombardia, L. Sanchez and J.I. Casal, Proteomic expression analysis of colorectal cancer by two-dimensional differential gel electrophoresis, Proteomics 5 (2005), 2602-2611.

[22] R. Chen, S. Pan, T.A. Bretnall and R. Aebersold, Proteomic profiling of pancreatic cancer for biomarker discovery, Mol Cell Proteomics 4 (2005), 523-533.

[23] D.B. Friedman, S. Hill, J.W. Keller, N.B. Merchant, S.E. Levy, R.J. Coffey and R.M. Caprioli, Proteome analysis of human colon cancer by two-dimensional difference gel electrophoresis and mass spectrometry, Proteomics 4 (2004), 793-811.

[24] P.R. Jungblut, U. Zimny-Arndt, E. Ziendl-Eberhart, J. Stulík, K. Koupilova, K.P. Pleissner, A. Otto, E.C. Müller, W. Sokolowska-Köhler, G. Grabher and G. Stöffler, Proteomics in human disease: Cancer, heart and infectious diseases, Electrophoresis 20 (1999), 2100-2110.

[25] M.R. Emmert-Buck, J.W. Gillespie, C.P. Pawaletz, D.K. Ornstein, V. Basrur, E. Appella, Q.H. Wang, J. Huang, N. Hu, P. Taylor and E.F. Petricoin, An approach to proteomic analysis of human tumors, Mol Carcinog 27 (2000), 158-165.

[26] F.J. Esteva and G.N. Hortobagyi, Prognostic molecular markers in early breast cancer, Breast Cancer Res 6 (2004), 109118.

[27] A. Tsugita and M. Kamo, 2-D electrophoresis of plant proteins, in: Methods in Molecular Biology Vol 112: 2-D Proteome Analysis Protocols, A.J. Link, ed., Humana Press, Totowa, 1999, pp. 95-97.
[28] U.K. Laemmli, Cleavage of structural proteins during the assembly of the head of bacteriophage T4, Nature 227 (1970), 680-685.

[29] M.I. Othman, M.I. Majid, M. Singh, S. Subathra, L. Seng and L.H. Gam, Proteomics of Grade 3 infiltrating ductal carcinoma in Malaysian Chinese breast cancer patients, Biotehcnol Appl Biochem 52 (2009), 209-219.

[30] M. Laurière, A semidry electroblotting system effieciently transfers both high- and low-molecular weight proteins separated by SDS-PAGE, Anal Biochem 212 (1993), 206-211.

[31] P.D. Nash, M. Opas and M. Michalak, Calreticulin: Not just another calcium-binding protein, Mol Cell Biochem $\mathbf{1 3 5}$ (1994), 71-78.

[32] L. Bini, B. Magi, B. Marzocchi, F. Arcuri, S. Tripodi, M. Cintorino, J.C. Sanchez, S. Frutiger, G. Hughes, V. Pallini, D.F. Hochstrasser and P. Tosi, Protein expression profiles in human breast ductal carcinoma and histologically normal tissue, Electrophoresis 18 (1997), 2832-2841.

[33] K. Chahed, M. Kabbage, B. Hamrita, C.L. Guillier, M. Trimeche, S. Remadi, L. Ehret-Sabatier and L. Chouchane, Detection of protein alterations in male breast cancer using two dimensional gel electrophoresis and mass spectrometry: The involvement of several pathways in tumorigenesis, Clin Chim Acta 388 (2008), 106-114.

[34] B. Franzén, S. Linder, A.A. Alaiya, E. Eriksson, K. Fujioka, A.C. Bergman, H. Jörnvall and G. Auer, Analysis of polypeptide expression in benign and malignant human breast lesions, Electrophoresis 18 (1997), 582-587.

[35] A. Aitken, 14-3-3 and its possible role in co-ordinating multiple signaling pathways, Trends Cell Biol 6 (1996), 341-347.

[36] H. Fu, R.R. Subramaniam and S.C. Masters, 14-3-3 proteins: Structure, function and regulation, Аппи Rev Pharmacol Toxico 40 (2000), 617-647.

[37] P. Russell, Checkpoints on the road to mitosis, Trends Biochem Sci 23 (1998), 399-402.

[38] E.M. Skoulakis and R.L. David, 14-3-3 proteins in neuronal development and function, Mol Neurobiol 16 (1998), 269284.

[39] M.B. Yaffe, How do 14-3-3 proteins work? - Gatekeeper phosphorylation and the molecular anvil hypothesis, FEBS Lett 513 (2002), 53-57.

[40] H. Hermeking, The 14-3-3 cancer connection, Nat Rev Cancer 3 (2003), 931-943.

[41] G. Tzivion, Z. Luo and J. Avruch, A dimeric 14-3- protein is an essential cofactor for Raf kinase activity, Nature 394 (1998), $88-92$.

[42] A.S. Vercoutter-Edouart, J. Lemoine, X. Le Bourhis, B. Boilly, V. Nurcombe, F. Révillion, J.P. Reyray and H. Hondermarck, Proteomic analysis reveals that 14-3-3 sigma is downregulated in human breast cancer cells, Cancer Res 61 (2001), 76-80.

[43] L. Zang, D. Palmer Toy, W.S. Hancock, D.C. Sgroi and B.L. Karger, Proteomic analysis of ductal carcinoma of the breast using laser capture microdissection, LC-MS, and 160/180 isotopic labeling, J Proteome Res 3 (2004), 604-612.

[44] D.A. Shaywitz, L. Orci, M. Ravazzola, A. Swaroop and C.A. Kaiser, Human SEC13Rp functions in yeast and is located on transport vesicles budding from the endoplasmic reticulum, $J$ Cell Biol 128 (1995), 769-777.

[45] A. Swaroop, T.L. Yang-Feng, W. Liu, L. Gieser, L.L. Barrow, K.C. Chen, N. Agarwal, M.H. Meisler and D.I. Smith, Molecular characterization of a novel human gene, SEC13R, related to the yeast secretory pathway gene SEC13, and mapping to a conserved linkage group on human chromosome 3p24-p25 
and mouse chromosome 6, Hum Mol Genet 3 (1994), 12811286.

[46] B.L. Tang, F. Peter, J. Krijnse-Locker, G. Griffiths and W. Hong, The mammalian homology of yeast Sec13p is enriched in the intermediate compartment and is essential for protein transport from the endoplasmic reticulum to the Golgi app- aratus, Mol Cell Biol 17 (1997), 256-266.

[47] P. Bellwood, Economic patterns of neolithic life, in: Encyclopedia of Malaysia: Early history, N.H.S.N.A. Rahman, ed., Editions Didier Millet, Kuala Lumpur, 1998, pp. 51-52.

[48] C. Palmieri, R.C. Coombes, S.B. Kim and S. Cleator, Ethnicity and breast cancer research, Lancet 372 (2008), 188-189. 


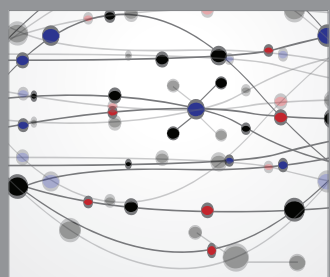

The Scientific World Journal
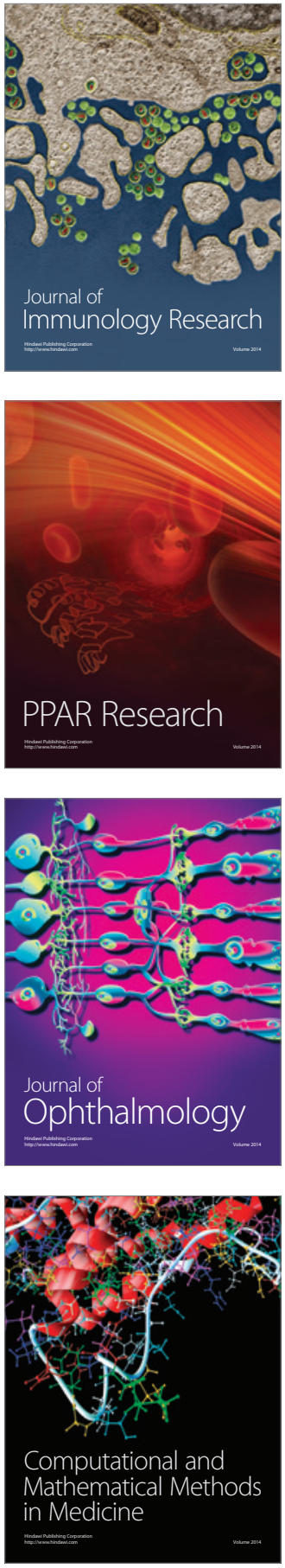

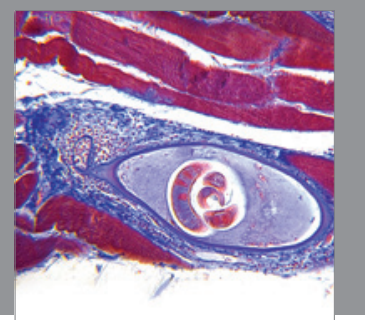

Gastroenterology

Research and Practice
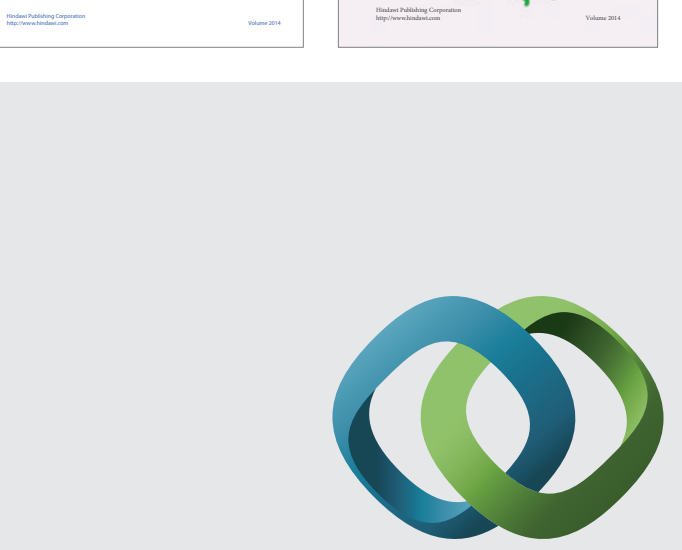

\section{Hindawi}

Submit your manuscripts at

http://www.hindawi.com
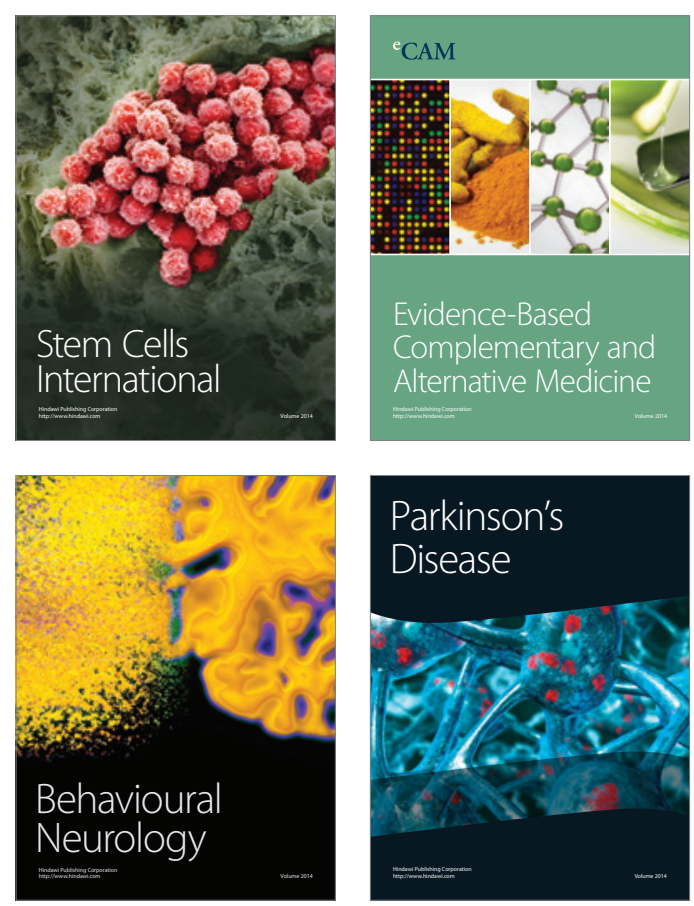

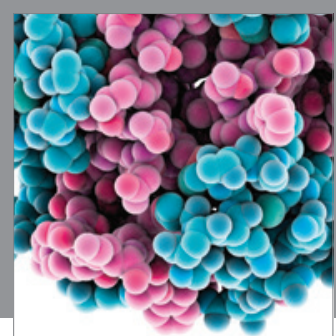

Journal of
Diabetes Research

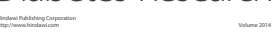

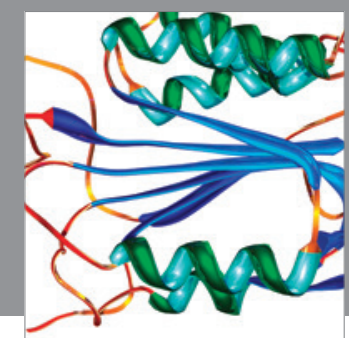

Disease Markers
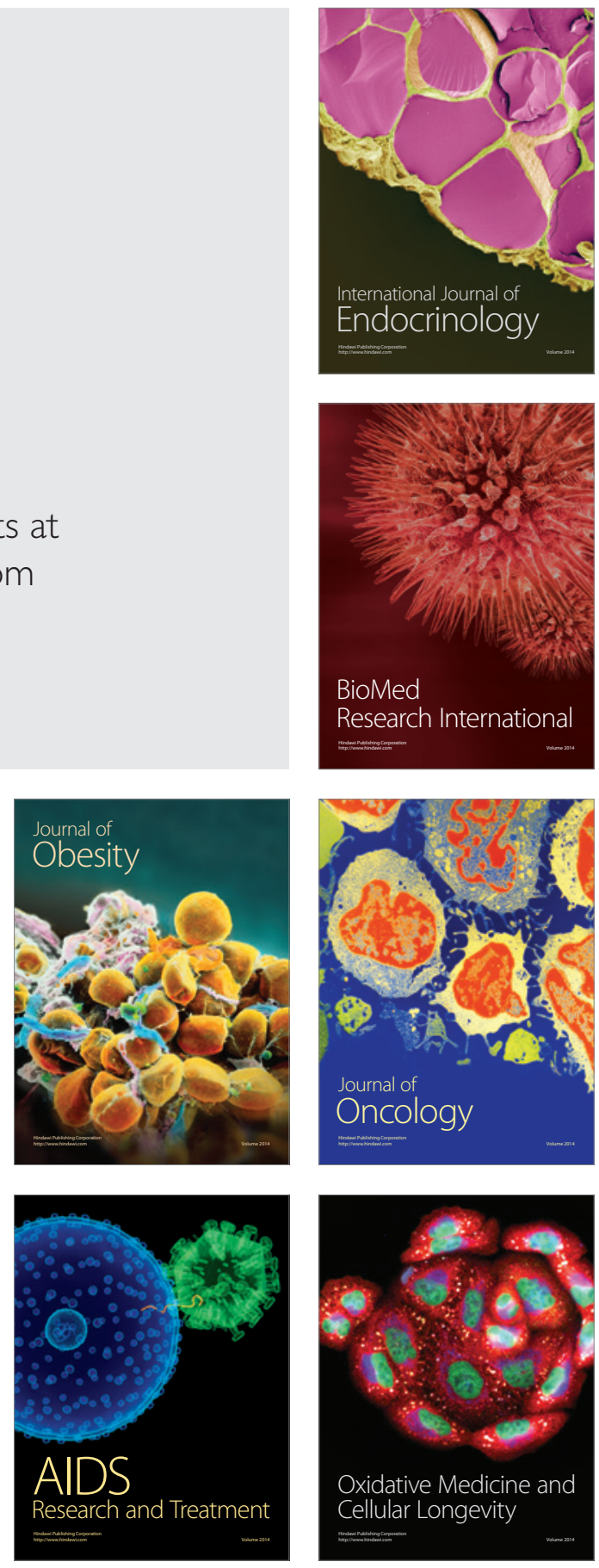